\title{
Plants under Stress: Involvement of Auxin and Cytokinin
}

\author{
Agnieszka Bielach, Monika Hrtyan and Vanesa B. Tognetti * \\ Mendel Centre for Plant Genomics and Proteomics, Central European Institute of Technology (CEITEC), \\ Masaryk University, Kamenice 5, Czech 62500, Brno, Czech Republic; agnieszka.bielach@ceitec.muni.cz (A.B.); \\ monika.hrtyan@ceitec.muni.cz (M.H.) \\ * Correspondence: vanesa.tognetti@ceitec.muni.cz; Tel.: +420-5-4949-6582; Fax: +420-5-4949-2640
}

Received: 18 May 2017; Accepted: 27 June 2017; Published: 4 July 2017

\begin{abstract}
Plant growth and development are critically influenced by unpredictable abiotic factors. To survive fluctuating changes in their environments, plants have had to develop robust adaptive mechanisms. The dynamic and complementary actions of the auxin and cytokinin pathways regulate a plethora of developmental processes, and their ability to crosstalk makes them ideal candidates for mediating stress-adaptation responses. Other crucial signaling molecules responsible for the tremendous plasticity observed in plant morphology and in response to abiotic stress are reactive oxygen species (ROS). Proper temporal and spatial distribution of ROS and hormone gradients is crucial for plant survival in response to unfavorable environments. In this regard, the convergence of ROS with phytohormone pathways acts as an integrator of external and developmental signals into systemic responses organized to adapt plants to their environments. Auxin and cytokinin signaling pathways have been studied extensively. Nevertheless, we do not yet understand the impact on plant stress tolerance of the sophisticated crosstalk between the two hormones. Here, we review current knowledge on the function of auxin and cytokinin in redirecting growth induced by abiotic stress in order to deduce their potential points of crosstalk.
\end{abstract}

Keywords: auxin; cytokinin; abiotic stress; crosstalk; growth; adaptation; ROS

\section{Introduction}

More than half a century has elapsed since the discovery that the phytohormones auxin and cytokinin are required to induce cell division and growth in plant tissue culture [1]. Since then, the two phytohormones have been recognized as the main regulators of plant development [2-11]. It is not surprising, therefore, that their biology has been studied extensively and that the underlying mechanisms of their action have captivated several generations of scientists. These two hormones have specific biosynthetic, homeostasis, transport and signal transduction pathways, which by now are well described. The literature on these topics is so comprehensive that it is impossible to encompass the information on auxin and cytokinin biology in this review [12-18]. In recent years, auxin and cytokinin crosstalk has been studied extensively at all levels (synthesis, perception and transport), and we are beginning to understand how these networks interact to control a wide variety of plant responses [3,8,19-22].

As sessile organisms, plants are continuously exposed to an enormous amount of external stimulus. Such external stimuli include, for example, a wide and diverse range of extreme weather conditions, which may appear unpredictably. Being aerobic organisms, plants use reactive oxygen species as a signaling molecule. However, if the accumulation of reactive oxygen species (ROS) occurring under suboptimal growth conditions, such as abiotic stresses, reaches toxic levels, their oxidative effects on plant cells can be lethal. Therefore, plants have developed mechanisms enabling quick recognition, distinction and response during a stressful encounter by, on the one hand, 
maintaining ROS levels at nontoxic concentrations through a complex battery of antioxidant systems and, on the other hand, by ROS interacting with phytohormone pathways [23,24]. To survive and adapt to new conditions, many plants redirect their growth through various morphological, physiological and biochemical responses that decrease stress exposure, limit damage or facilitate the repair of damaged systems. In other words, plants have managed to acquire an escape or survival strategy to deal with stress by modifying some of their morphological and physiological traits. In particular, cooperative action of the two phytohormones auxin and cytokinin with stress-induced ROS signals connects plant development with plant responses to environmental changes [25-31]. The resulting crosstalk between ROS and auxin and cytokinin allows plants to adjust their development and growth to unfavorable external cues. In this review, we focus on the roles of auxin and cytokinin in plant growth and development while emphasizing two major areas: (i) how plants maintain growth via balancing both hormonal pathways along with ROS signals; and (ii) inferring potential stress-auxin-cytokinin crosstalk regulatory hubs that might act as pivotal junctions between the hormone orientation and stress-induced plant growth.

\section{Role of Auxin and Cytokinin during Plant Response to Abiotic Stress}

Physiological and genetic studies have dissected the functions of individual hormonal pathways in different developmental contexts, and recent advances have shown that hormones act through a network of interacting responses rather than through isolated linear pathways [22]. Here, we focus on the effect of abiotic stress on the control points of auxin and cytokinin pathways, which could explain in part the stress-induced changes in plant architecture and growth patterns. We summarize how abiotic stress influences auxin and cytokinin concentrations, transport and responses. At the same time, we would like to draw attention to important checkpoints for approaches in modern biotechnology aiming to improve plant yields under stress conditions. The genes from cytokinin and auxin pathways studied to date that respond to abiotic stress, as well as their respective roles in stress-tolerance are summarized in Supplementary Table S1.

\subsection{Targets of Auxin and Cytokinin Biosynthesis Modulated by Stress}

The youngest leaves containing the largest amounts of auxin exhibit the greatest capacity for de novo auxin synthesis [32] and usually exhibit increased stress avoidance [33]. Recent findings suggest that a functional YUCCA (YUC) pathway of auxin biosynthesis may be exploited to alter plant responses to the environment [34-36]. In Arabidopsis thaliana and barley (Hordeum vulgare), for example, inhibition of the expression of YUC2 and YUC6 genes by high temperatures leads to a local decrease in endogenous auxin levels in developing anthers, which in turn results in male sterility [37,38]. Exogenous application of indole-3-acetic acid (IAA) efficiently rescues male sterility in both species [38]. This suggests that tissue-specific decrease in auxin is the primary response to such environmental change as an increase in temperature, which leads to the abortion of pollen development and, as a result, a decrease in yield. Additionally, Arabidopsis plants overexpressing YUC6 or transgenic poplar expressing Arabidopsis YUC6 under the control of the oxidative stress-inducible SWPA2 promoter display enhanced IAA-related phenotypes and exhibit improved drought and oxidative stress resistance $[39,40]$. Recent studies show that besides harboring a flavin-containing monooxygenase (FMO) domain involved in IAA biosynthesis, YUC6 contains FADand NADPH-dependent thiol-reductase activity (TR) domains overlapping with the FMO domain. Interestingly, the stress-related phenotypes of YUC6 overexpressors do not appear to be linked to IAA overproduction, but rather to TR activity of YUC6 [39]. Moreover, the auxin level increased by constitutive overexpression of the Arabidopsis YUC6 gene in potato (Solanum tuberosum) [34,36] or overexpression of the TRYPTOPHAN-2-MONOOXYGENASE known as iaaM in Arabidopsis enhances drought tolerance [41]. Drought-resistant phenotype was correlated with auxin-dependent decrease in $\mathrm{H}_{2} \mathrm{O}_{2}$ and $\mathrm{O}_{2-}$ [34,36,41]. Elevated auxin positively modulates the expression levels of multiple abiotic stress-related genes (RAB18, RD22, RD29A, RD29B, DREB2A and DREB2B) and positively 
affects antioxidant enzyme activities. Interestingly, drought-resistant phenotype, reduction in ROS accumulation, induction of stress-related genes and activation of antioxidant response can be mimicked by exogenous application of IAA. In contrast, lower levels of auxin in yuc1 yuc2 yuc6 triple mutants lead to increased ROS accumulation and decreased drought tolerance [41].

It is known that drought resistance is closely related to the root-to-shoot ratio of biomass [42,43]. The YUC7 gene is induced by drought primarily in the roots, and elevated levels of free auxin in Arabidopsis activation-tagged mutant yuc7-1D promotes root growth and enhances root architecture. Accordingly, yuc7-1D plants are resistant to drought and show upregulation of drought-responsive genes [35]. Mutation in the rice (Oryza sativa) CONSTITUTIVELY WILTED1 (COW1) gene, which encodes a new member of the YUC protein family, leads to a lower root-to-shoot ratio of biomass and, as a consequence, unbalanced water homeostasis [42].

Active cytokinins are adenine derivatives with isoprenoid or an aromatic side chain attached to the N-6-position of the adenine ring. The most common group present in plants has an isoprenoid side chain and includes isopentenyladenine (iP)-, trans-zeatin (tZ)-, cis-zeatin (cZ)- and dihydrozeatin-type derivatives [44]. Less abundant are aromatic cytokinins, such as N6-(meta-hydroxybenzyl) adenine [45]. The rate-limiting step of cytokinin biosynthesis is the production of the cytokinin precursor isopentenyladenine catalyzed by ATP/ADP isopentenyltransferases (IPT). Subsequently, cytochrome P450 monooxygenases CYP735A1 and CYP735A2 catalyze the hydroxylation of isopentenyladenine-type cytokinins. Moreover, enzymes from the LONELY GUY (LOG) family convert N6-modified adenosine monophosphate derivatives into active cytokinins. Finally, cytokinins undergo irreversible degradation by oxidative side chain cleavage catalyzed by CYTOKININ OXIDASE/DEHYDROGENASE (CKX) enzymes [46]. Recent findings on cytokinin biosynthesis and signaling help to fill important gaps in the understanding of how environmental cues interact with these components to modulate plant growth development and physiology. Cytokinin function has been linked to a variety of abiotic stresses $[47,48]$. A decline in endogenous cytokinin levels in reaction to stress has long been observed $[49,50]$. In xylem sap, drought stress reduces the levels of trans-zeatin, zeatin riboside, isopentenyl adenine and isopentenyl adenosine [51]. Additionally, the transport of trans-zeatin riboside decreases drastically [52,53]. The same treatment, however, increases the amount of cytokinin 6-benzylaminopurine, suggesting that benzylaminopurine might play a role in response to stress by delaying stress-induced leaf senescence [54]. Additionally, the high concentration of benzylaminopurine induces accumulation of the osmolyte proline [55].

Participation by cytokinin biosynthesis and degradation enzymes in response to stress is likely to be dependent on their spatial and temporal expression patterns. Genetic studies in which the endogenous cytokinin levels in Arabidopsis were modified, either by loss of expression of IPT genes or by overexpression of CKX-encoding genes, show that cytokinin plays a negative role in response to stress [43,56-60]. Despite their being detrimental for shoot growth, analysis of Arabidopsis CKX overexpressor lines (35S:CKX1, 35S:CKX2, 35S:CKX3, 35S:CKX4) and of ipt1 ipt3 ipt5 ipt7 mutants has revealed that a reduction in cytokinin levels improves drought and salt stress tolerance [58,61]. The use of root-specific promoters prevents drawback on shoot growth. For example, targeting AtCKX1 overexpression only in roots in Arabidopsis and tobacco (Nicotiana tabacum) results in plants with larger root systems, but has no influence on shoot growth and development. Similarly, those plants exhibit higher tolerance to drought and heat stress, associated in part with the improvement in root traits [43,57]. The role of cytokinin subcellular compartmentation in roots was recently studied in transgenic barley plants overexpressing the AtCKX1 gene targeted to various subcellular compartments and under the control of the mild, root-specific $\beta$-glucosidase promoter from maize (Zea mays) [59]. While the assumed cytosolic and vacuolar targeting of AtCKX1 had a negligible effect on shoot growth, secretion of the AtCKX1 protein to the apoplast had a negative effect on the development of the aerial part and on yield. Upon application of severe drought stress, all transgenic genotypes maintained a higher water potential and showed better growth and yield parameters during revitalization. The higher tolerance to drought stress exhibited by all transgenic barley plants was deliberately 
caused by the altered root morphology that resulted in better dehydration avoidance [59]. Therefore, morphological variations caused by altered cytokinin levels in roots or shoots play a decisive role in plant stress performance. These data highlight the importance of locally informative cytokinin signals generated by localized production and/or degradation of cytokinin for morphological changes to create stress avoidance and tolerance.

The relevance of cytokinin level fluctuations throughout stress episodes, as well as of tissue type where such changes occur has been demonstrated by employing inducible promoters. The importance of inducing cytokinin production specifically during the onset of water stress to increase plant stress performance was confirmed by driving the expression of the Agrobacterium tumefaciens IPT gene by the leaf-specific drought and maturation responsive promoter of the SENESCENCE ASSOCIATED RECEPTOR PROTEIN KINASE (SARK). This strategy (SARK::IPT) has been used with tobacco [62], rice [63], peanut (Arachis hypogaea) [64], cotton (Gossypium) [65] and maize plants [66]. SARK promoter-regulated expression of the IPT gene suppresses drought-induced leaf senescence by allowing plants to produce cytokinin in tissues sensing water stress [67]. Remarkably, transgenic tobacco $S A R K:: I P T$ plants exhibited outstanding drought tolerance and vigorous growth after a long drought period that killed the control plants [67]. Similarly, water-stressed transgenic maize SARK::IPT plants maintained a normal photosynthetic rate and stomatal conductance. Moreover, transgenic plants recorded only a minor decrease in the number of grains per plant, individual grain weight and plant grain yield as compared to well-watered plants [66]. Improved drought tolerance in creeping bentgrass (Agrostis stolonifera) expressing senescence-associate promoter SAG12:IPT constructs leads to an increase in endogenous iP and Z-riboside content in leaves and roots and positively effects osmotic adjustment, efficient water use and photosynthesis maintenance [68]. In these plants, high levels of cytokinin promote ROS scavenging through antioxidant accumulation and activation of antioxidant enzymes in roots and shoots. Moreover, the increment of cytokinin synthesis in the root meristem was proven to be a good tool to alleviate drought inhibition of root growth [69]. On the other hand, a negative effect on stress adaptation was observed by ectopic overproduction of endogenous cytokinin. Arabidopsis estradiol-inducible IPT8 transgenic seedlings, in which estradiol and salt stress treatments were performed simultaneously, were more sensitive to stress, as indicated by reduced survival rates and chlorophyll content [70]. In tomato (Solanum lycopersicum), however, the constitutive endogenous expression of SIIPT3 led to a stress-adapted phenotype [71], which is characterized by a more compact rosette size and increased shoot branching [72]. Moreover, increased cytokinin levels in young and old leaves caused several other changes that affected nutrient accumulation and photosynthesis maintenance and led to enhanced performance against salt stress. SIIPT3 is highly expressed in old leaves and roots. In response to salt stress, its transcription is strongly repressed in tomato roots and significantly induced in young and old leaves [71]. These data suggest that increasing the cytokinin content in shoots before the onset of stress acts as a pre-adapted factor, triggering the necessary morphological alterations to prevent the negative effects of stress on plant physiology.

The importance of tissue-specific cytokinin metabolism for adaptation against stress is evidenced by comparing the activity levels of cytokinin biosynthesis enzymes between resistant and susceptible crop varieties. In rice, for example, cytokinin metabolism is particularly relevant for panicle differentiation and grain yield, and it is known that $L O G$ and CYP735A genes' expression is altered by various abiotic stress conditions [73,74]. Interestingly, LOG, IPT and CYP735A enzyme activities in panicles are similar in heat-susceptible rice varieties and in heat-tolerant variety SY63 at high temperature stress. However, the stress-induced increment of total CKX activity is specific to the susceptible varieties. Moreover, reduction of cytokinin transport from root to shoot via xylem sap and decreased LOG and IPT activities seem to be responsible for the lower number of spikelets per panicle obtained under high temperature treatments in the susceptible lines [75]. Similarly, increased CKX activity was observed under high temperature stress in tobacco plants [56]. These results suggest that cytokinin catabolism is involved in high temperature stress adaptation in rice and tobacco plants. Therefore, modulation of CKXs activity represents an interesting genetic tool 
to increase plant yield under stress. Consistent with this assumption, knockdown rice mutants for the inflorescence meristem specific OsCKX2 gene lead to increased primary and secondary panicle branching and growth. The effect is associated with increased $t Z$, iP, kinetin and dihydrozeatin levels in the inflorescence meristem. Moreover, OsCKK2 RNAi lines better tolerate salt stress showing decreased growth penalties, higher number of panicles, increased levels of photosynthetic pigments and photosynthetic rates, improved water content and decreased oxidative damage determined by electrolyte leakage [76].

At a molecular level, changes in cytokinin concentrations influence stress responses most probably by altering ROS production. Cytokinin-treated plants or mutants with altered cytokinin production or degradation exhibit ROS homeostasis imbalance, which in turn would have an effect on the activity of ROS-scavenging enzymes, on lipid peroxidation and on the expression of genes involved in photosynthesis and abiotic stress responses [56,58,69,70,77-81].

A detailed transcriptomic analysis of barley plants expressing CKX1 in roots revealed attenuated cytokinin response through the HvHK3 cytokinin receptor and upregulation of two transcription factors implicated in stress responses [59]. RNA-seq analysis further suggests crosstalk with auxin as several SAUR and Aux/IAA genes exhibited lower expression in transgenic plants than in wild types, thus indicating higher auxin turnover in transgenic roots [60].

\subsection{Stress-Induced Modulation of Auxin and Cytokinin Metabolic Routes}

Extracellularly-secreted plant peroxidases, which catalyze the decomposition of peroxides, are involved in the catabolic oxidation of IAA. These oxidase-associated auxin oxidase activities impact auxin stability and level [82], as observed in UV-treated tobacco and duckweed (Spirodela punctate and Lemna gibba) plants [83]. Furthermore, IAA peroxidases are important for the control of IAA levels during root initiation and development [84] and during the process of hypocotyl elongation [85]. Abiotic stress also affects the expression of genes involved in auxin metabolism $[24,86]$. Auxin UDP-glucosyltransferases are strongly induced under photorespiration and $\mathrm{H}_{2} \mathrm{O}_{2}$-inducing conditions [87]. Arabidopsis UDP-glucosyltransferase UGT74E2 catalyzes the addition of glucose (glc) preferably to the auxin indole-3-butyric acid (IBA) [72]. Interestingly, ectopic overexpression of UGT74E2 in Arabidopsis not only increases IBA-glc concentrations, but also elevates free IBA and modifies the conjugated IAA pattern. Additionally, perturbed auxin homeostasis in transgenic plants steers architectural changes, including increased shoot branching and altered rosette shape, and it leads to enhanced drought and salt stress resistance. Moreover, IAA-glc and IBA-glc levels increase in wild-type and overexpressor plants under osmotic stress [72]. Recently, another UDP-glucosyltransferase was shown to play a role in stress response. Arabidopsis plants constitutively expressing the stress-regulated UGT85U1 gene isolated from stigmas of saffron (Crocus sativus) exhibit enhanced salt and oxidative stress tolerance. Although auxin levels and PIN2 expression in the roots are higher in UGT85U1 overexpressors as compared to wild-types, there are no data regarding its targets or its implication in hormone homeostasis [88]. Stress-induced changes in the endogenous auxin pool can also be regulated through negative feedback by auxin-inducible GRETCHEN HAGEN 3 (GH3) enzymes, which catalyze amide conjugation of IAA with amino acids [89]. GH3 gene expression has been induced in different species by various stress conditions, such as drought, salinity, cold and heat [90-93]. The rice OsGH3-2 gene is induced by drought and suppressed by cold, and its overexpression causes significant morphological aberrations related to IAA deficiency, reduced free IAA levels, greater stomata aperture, faster water loss and hypersensitivity to drought stress [90]. Moreover, salinity stress has been shown to decrease free IAA concentration [92,94], and poplars can use IAA-amide conjugates as a source of auxin to balance the effects of salt stress on auxin content [94]. Overexpression of the Arabidopsis GH3 gene WES1 leads to reduced growth and increased stress tolerance by promoting the IAA-aspartate catabolic pathway [91]. In rice, activation of TLD1, a GH3.13 gene, which is suppressed in aboveground tissues under normal conditions, but dramatically induced by drought stress, compensates for alterations in plant architecture and tissue patterning with an 
increased drought tolerance [93]. Chickpea (Cicer arietinum) CaGH3-1 and -7 and Medicago truncatula $M t G H 3-7,-8$ and -9 were also found to be highly induced under drought and/or salt stresses, suggesting their role in abiotic stress responses [95]. In maize, the responsiveness of $Z m G H 3$ genes to a wide range of abiotic stresses and stress-related hormones suggests that $\mathrm{ZmGH3s}$ are auxin-stress crosstalk regulatory targets. Moreover, the expression of $\mathrm{ZmGH3}$ genes showed different patterns between shoot and root [96]. IAA-ALANINE RESISTANT 3 (IAR3), an IAA-alanine hydrolase that releases bioactive IAA from IAA-alanine, is another component of the ROS-auxin crosstalk regulatory network involved in stress adaptation. Arabidopsis roots sensing high osmotic stress signal the repression of miRNA167, which targets IAR3 mRNA. In turn, upregulation of IAR3 [97] underpins increased local IAA levels, changes in root architecture and increased stress tolerance. In conclusion, even if IAA conjugates are considered to be either reversible or irreversible storage compounds, a direct signaling function of these conjugates in various processes including stress responses cannot be excluded. For example, Arabidopsis seedlings treated with IBA or IBA-glc delayed flower induction [72] and recently IAA-aspartate were suggested to have a direct and specific effect on salinity and heavy metal stress responses in pea plants [98].

Glycosylation of cytokinin also plays an important role during stress responses. Cytokinins mainly exist in the form of conjugations in plants. Reversible glycosylation of cytokinins ( $O$-glycosylation and $\mathrm{O}$-acetylation) creates as stable storage forms of the hormone. $\mathrm{N}$-glycosylation of cytokinin is thought to be irreversible. In Arabidopsis, UGT76C1 and UGT76C2 catalyze N-glycosylation of most cytokinin species, while UGT85A1, UGT73C1, and UGT73C5 catalyze O-glycosylation of $\mathrm{tZ}$ and dihydrozeatin [18]. The Arabidopsis UGT76C2 catalyzes the glycosylation of all classical cytokinins and is transcriptionally downregulated by osmotic and drought stresses. Plants overexpressing UGT76C2 are sensitive to mannitol during germination, but tolerant to drought stress as adult plants. In contrast, the knockout $u g t 76 c 2$ mutants show the opposite responses to both stresses, indicating a protective role against stress at the adult developmental stage [99]. It is known that local overproduction of endogenous cytokinin and auxin can control stress-adaptation responses by modulating ROS homeostasis [70,72]. Therefore, tissue-specific ROS levels could act as an integrator of the responses triggered by both pathways and relevant for stress-induced growth shaping. Reciprocally, direct auxin and cytokinin oxidation by spontaneous reaction with increased local ROS accumulation $[100,101]$ may act as an alternative ROS energy dissipation pathway, albeit one minor in relevance as compared to enzyme-catalyzed degradation.

\subsection{Modulation of Auxin and Cytokinin Transport by Stress}

The hallmark of stressed plants is the accumulation of flavonoids, which seem to be negative regulators of polar auxin transport [101-104] and lead to the activation of auxin-dependent stress responses [105]. It is known that flavonoids affect the expression, localization and recycling of PINs, as well as the activity of ABCB-type auxin transporters [106-109]. Alteration of flavonoid accumulation in flavonoid-deficient mutants affects lateral root initiation and root architecture [110]. The WRKY23 gene is induced by auxin and encodes a member of the large WRKY family, a plant-specific class of transcription factors that has been associated with responses to pathogen attack, mechanical stress and senescence [111]. WRKY23 controls proper root growth and development by stimulating the local biosynthesis of flavonols, a subgroup of flavonoids [112]. GLUTATHIONE S-TRANSFERASE Phi 2 (GSTF2) transcripts are expressed in the shoot-root transition zone and root distal elongation zone of seedlings, and they respond to auxin and oxidative stress treatments. Competition between IAA and flavonoids for binding to GSTF2 may contribute to the regulation of auxin transport under normal and detrimental growth conditions [113]. By controlling the processes of auxin transport and distribution, flavonoids modulate not only plant responses to stresses, but also the development of stress induced morphogenetic responses, which alter plant growth and development in order to decrease damage of tissues or organs caused by stressors [86]. For example, peroxidase-catalyzed oxidation of IAA during UV stress is promoted by flavonoids and modulates leaf and plant architecture [83]. In opposition, 
auxin affects flavonoid metabolism by inducing UDP-glucose:flavonoid 3-O-glucosyltransferase activity [114]. An interesting recent model proposes that flavonols function as positional signals, integrating auxin, cytokinin and ROS signaling in root meristem to control root light avoidance and root growth [115]. An additional level of complexity to the possible ways by which flavonols influence auxin distribution is seen in the finding that flavonol glycosides affect auxin metabolic turnover [104].

Given that they are responsible for the asymmetric distribution of auxin, it is scarcely surprising that some components of the polar cell-to-cell auxin transport machinery are primary targets of environmental signals. Interestingly, synthetic polar auxin transport inhibitors 2,3,5-triiodobenzoic acid and 1-N-naphthylphthalamic acid induce morphological changes similar to those imposed by stress, including decreased root elongation, increased root hair density, decreased leaf size, inhibition of mesophyll cell expansion and fluctuations in chlorophyll content $[72,116]$. Temporal-spatial patterns of PIN FORMED (PIN) auxin efflux carriers and their subcellular localization cooperatively modulate stress-induced reorientation of growth. In Arabidopsis roots, for example, salinity treatments in 21-day-old seedlings were shown to induce expression of PIN1, PIN3 and PIN7 genes [117], while in seven-day-old seedlings, mRNA and protein levels were significantly reduced [118]. In the case of PIN2, five-day-old seedlings downregulated its expression in response to salinity [119], while high osmotic stress imposed by mannitol upregulated PIN3 expression in adult plants [97]. Inter- and intra-cellular auxin transport is also mediated by AUX1/LAX (AUXIN RESISTANT1/LIKE-AUX1) influx transporters, ATP Binding Cassette (ABC) transporters and putative auxin transporters PILS (PIN-LIKES). Transcriptional analysis in maize revealed that stress responsive ZmLAX, ZmPIN, ZmPILS and $Z m A B C B$ genes have the opposite expression pattern in shoots and roots during salt, drought or cold treatments [120].

Dynamic subcellular PIN localization visible as a constitutive endocytic recycling [121] provides a plausible mechanism for rapid reshuffling of PIN proteins between different sides of the cell [122]. Thus, changes in PINs' polar localization in response to different developmental or environmental signals could dynamically change the auxin flow, with a concomitant impact on physiological and morphological processes of the plant [123-127]. Cold stress has been shown to inhibit basipetal auxin transport by interfering with the trafficking of PIN2. Short-term cold stress application did not affect the asymmetric localization of PIN2, but suppressed cellular trafficking. Moreover, lateral relocalization of PIN3, which mediates the early phase of root gravity response, was also inhibited by cold stress in Arabidopsis roots [128]. It was recently shown that osmotic perturbation influences the balance between endocytosis and exocytosis in root meristem. Acute hyperosmotic stress attenuates exocytosis by boosting clathrin-mediated endocytosis, whereas the opposite effect is observed from hypo-osmotic stress treatments [129]. In addition, as an adaptive mechanism, changes in auxin redistribution in root tips triggered by salt-induced endocytosis of PIN2 allow directional bending of the root away from the stressor [130]. However, knowledge as to the molecular mechanism involved in membrane trafficking of polar-localized PINs upon stress is still limited. Therefore, to obtain a more comprehensive view on how auxin flux is adapted in response to stress, more focused studies are needed on cellular regulation of membrane traffic under stress.

In contrast to auxin, little is known about cytokinin cell-to-cell transport, and consequently, its role in plant adaptation under abiotic stress conditions remains as yet undiscovered. The presence of cytokinin in xylem and phloem sap indicates that cytokinin can be transported over long distances acropetally and basipetally [131-133]. Cytokinins are translocated by the xylem via acropetal transport, as tZ-ribosides from root to shoot [132,134], and by the phloem via basipetal transport as iP-type from shoot to root [135]. Moreover, basipetal transport of cytokinin occurs through symplastic connections in the phloem and stabilizes the root vasculature pattern [136]. Two purine permeases involved in cytokinins cellular transport have been described in Arabidopsis: PUP1 and PUP2 [132,134]. Transport studies in cell cultures and yeast indicated that adenine and cytokinins are transported by the PUP system. Direct measurements demonstrated that PUP1 is capable of mediating uptake of radiolabeled tZ, while PUP2 is able to transport a number of cytokinins. Presence of PUP2 in the phloem suggests a 
function in the long-distance transport of cytokinins [134]. In addition, entry of zeatin-type cytokinins into the xylem transport stream is regulated by ABCG14. This transporter is mainly expressed in the plasma membrane of pericycle and stellar cells of roots, overlapping with the expression pattern of IPT3 and CYP73A2, and it has been suggested to function as an efflux pump that plays an essential role for root to shoot translocation of the root-synthesized cytokinins [137,138]. ABCG14 could represent the major root-to-shoot transporter of cytokinin. However, the possibility that other transporters may also contribute in this process cannot be excluded.

Therefore, deciphering how auxin and cytokinin transport and distribution are linked by stress-adaptation responses represents a novel avenue with incredible potential for understanding the morphological changes and decreased growth rates observed in plants exposed to environmental hardships.

\subsection{Auxin and Cytokinin Signaling Circuits Influenced by Stress}

A decrease in the activity of the DR5:: GUS auxin marker [139] during drought [41,140], salt [118] or $\mathrm{O}_{3}$ stress [141] indicates stress-induced auxin signaling attenuation.

TIR1/AFB1-5 F-box nuclear auxin co-receptors [142] are involved in tolerance to stress. TIR1, $A F B 1, A F B 3$ and AFB5 expression is downregulated by oxidative stress [141]. Stress resilience in tir1 $a f b 2$ mutants was manifested by reduced accumulation of hydrogen peroxide and superoxide anions, as well as enhanced antioxidant enzyme activities under oxidative and salt stress. Moreover, tir 1 $a f b 2$ showed increased tolerance against salinity measured as chlorophyll content, germination rate and root elongation compared to wild-type plants [143]. Eight TIR1 homologous genes (PtrFBLs) in Populus trichocarpa differentially respond under heat stress, and 35S::PtrFBL1 plants exhibited increased susceptibility to drought stress [140].

Expression of many gene family members involved in nuclear auxin signaling, including auxin response factor (ARF) transcription factors and the early auxin-responsive genes (Aux/IAA, GH3, $S A U R$ and $L B D)$, is affected by abiotic hardships [141,144-146]. Moreover, stress modulation of auxin signaling also seems to be conserved in different plant species [141,143-146]. Comprehensive expression profiling of auxin-related genes in Sorghum bicolor revealed that three genes (SbIAA1, SbGH3-13, and SbLBD32) were highly induced under salt and drought treatment [146]. Furthermore, a detailed analysis of auxin signaling in Arabidopsis showed that transcripts of several Aux/IAA transcriptional repressors were reduced in response to $\mathrm{O}_{3}$-induced apoplastic $\mathrm{ROS}$, with the exception of IAA10 and IAA28 transcripts, the levels of which were transiently increased [141]. In rice, OsIAA6 was shown to be involved in drought stress. The overexpression of OsIAA6 under the constitutive phosphogluconate dehydrogenase (PGD) promoter (PGD1:OsIAA6) improves the tolerance of transgenic plants to drought. Moreover, transcript expression levels of the dehydration marker dehydration inducible protein 1 are repressed in PGD1:OsIAA6 as compared to wild-type plants. Additionally, it seems that OsIAA6-mediated drought responses might control auxin biosynthesis, as transgenic lines exhibit higher expression of YUC genes [147]. Abiotic stress can also influence auxin signaling by modulating AUX/IAAs stability. In Arabidopsis, salt-induced nitric oxide (NO) accumulation was proposed to lower free IAA pool size in root meristem by signaling the downregulation of PIN genes expression. As a result, stabilization of AUXIN RESISTANT3 (AXR3)/IAA17 protein led to the inhibition of root meristem growth [118]. In sorghum, salinity strongly induces many ARF genes in leaves while downregulating them in roots. Only SbARF10, SbARF16 and $S b A R F 21$ genes are induced in roots by salinity [146]. In contrast, most Arabidopsis ARF genes are negatively regulated by drought and salt stresses [148]. OsARF11 and OsARF15 in rice and GmARF33 and GmARF50 in soybean (Glycine max) are among the drought-responsive gene targets [144,145]. Abiotic stress regulation of ARF expression could occur in part via miRNAs, inasmuch as, for example, salt stress-induced miRNAs were shown to target ARFs in radish (Raphanus sativus) [149], and induction of Arabidopsis miRNA167 upon stress could cleave ARF6 and ARF8 transcripts [150].

In Arabidopsis, the cytokinin signaling cascade is a multi-step phosphorelay consisting of histidine protein kinase (AHK), histidine phosphotransfer proteins (AHPs) and response regulators (ARRs) [151]. 
ARRs are divided into two classes: type-A partially redundant negative regulators and type-B positive regulators [152-155]. While phosphorylation of type-A ARRs stabilizes them, phosphorylation of the type-B ARRs regulate transcription of cytokinin-activated targets, including type-A ARRs, which are strongly and rapidly induced in response to cytokinin [155-158]. These cytokinin signaling components' respective genes are differentially affected by various stresses [48]. The expression of the Arabidopsis cytokinin receptors $A H K 2, A H K 3$ and $A H K 4$ is rapidly induced by dehydration stress [159], suggesting that elevated cytokinin perception might play a role in stress response. AHK2 expression decreases by approximately half in the first hours after transfer to low water potential while AHK4 expression is only slightly changed [160]. Moreover, downstream components of the cytokinin signaling pathway respond to harsh environments. Transcripts of type-A ARR7 are induced by cold, drought and high salinity $[117,161,162]$, whereas ARR5, ARR6 and ARR15 are induced by salinity and dehydration stresses $[117,162,163]$. Heat stress downregulates in leaves the expression of $A H K 2$, $A H K 3$ and $A H K 4$ genes, as well as type-A ARR8 and ARR9 and type-B ARR10 and ARR12 response regulator genes [80]. The effect of cytokinin upon water deficiency is linked to ABA homeostasis and accumulation of the osmoprotectant proline [58,160]. Moreover, cytokinin redox control of plant development upon stress may be appreciated through its effect on the expression of stress-induced genes encoding proteins involved in secondary metabolism such as flavonoid and phenylpropanoid biosynthesis, a set of glutaredoxin, peroxidase and glutathione transferase genes and antioxidant enzyme genes [164-167]. We further will summarize here the efforts that have been made to work out the roles of the different components of the cytokinin signaling pathway on stress adaptation and response. Genetic analyses indicate that cytokinin receptors have tissue- and stress-specific function in abiotic stress response. Mutants lacking the functional cytokinin receptors are more resistant to drought, salt and cold stress $[159,161,168]$. The Arabidopsis loss-of-function ahk2 and ahk3 single mutants exhibit enhanced dehydration and salinity tolerance as compared to wild-type plants, and the effect is even more pronounced in the double ahk2 ahk3 mutant $[159,168]$. Similarly, ahk2 ahk3 and ahk3 ahk4 were significantly more resistant to freezing temperatures [161]. In the aforementioned works, the stresses imposed were severe or near lethal and shoot greenness and plant stress survival were used as indicators of stress resistance. Kumar and Verslues [160], however, used controlled mild stress conditions to study the effect of stress on growth by measuring root elongation and total fresh weight in seedlings. The enhanced root elongation phenotype of ahk3-3 mutants [169] was more pronounced at low water potential induced by polyethylene glycol, but neither increased root elongation, nor increased fresh weight were observed under chronic salt stress. However, ahk2-2 mutants were more sensitive to moderate severity of salt stress as measured by a greater reduction in root growth and decreased fresh weight as compared to the wild-type. The authors also found a synergistic effect in the fresh weight under chronic salt stress in ahk3 ahk4 double mutants, the weight of which was much less affected in shoots than in the cases of any of the other single or double mutants. Therefore, the data indicate a specific role for AHK2 in root growth during long-term salt stress and for AHK3 and AHK4 in response to decreased water potential in shoots [160].

Three Arabidopsis AHPs (AHP2, AHP3 and AHP5) control responses to drought stress in a negative and redundant manner. Loss of function of these three $A H P$ genes resulted in a strong, drought-tolerant phenotype that was associated with the stimulation of protective mechanisms, such as improvement in cell membrane integrity [170]. In rice, OsAHP1 and OsAHP2 were found to act as negative regulators of the osmotic stress response. The OsAHP RNAi rice plants displayed strong osmotic tolerance with increased root fresh weight [171]. In addition, a positive role of ARR1, AHP2, AHP3 and AHP5 was described during cold stress and mediated by regulating the expression of type-A ARRs. The arr 1 mutation, as well as ahp 2 ahp 3 ahp 5 triple mutations greatly reduced the cold induction of ARR5, ARR6, $A R R 7$ and ARR15 genes. Furthermore, it has been demonstrated that response to cold stress works downstream of AHK2 and AHK3 receptors [162]. Similarly, in response to salt stress, the activation of ARR1- and ARR12-dependent signaling pathways in roots could modulate ARR5 induction [172]. 
In addition to the core components of the cytokinin signaling pathway, other downstream targets have been linked to abiotic stress response. CYTOKININ RESPONSE FACTORS (CRFs), members of the APETALA2 (AP2) family, are transcriptionally upregulated by cytokinin and regulate transcription of a large portion of cytokinin-response genes, many of which are also differentially regulated by type-B ARRs [173]. Examination of tomato SlCRF1 and SlCRF2 transcripts during abiotic stress revealed that the two genes have patterns of regulation distinct from one another and between shoot and root tissues. Cold highly induced expression of SICRF1 in leaves and roots, whereas heat repressed its expression in roots. In contrast, SlCRF2 expression was induced in roots by oxidative stress [174]. In addition, analysis of Arabidopsis CRF6::GUS revealed that CRF6 promoter activity is elevated by endogenous production of hydrogen peroxide [175], under heat shock, as well as salt and oxidative stress conditions [176]. Moreover, constitutive overexpression of CRF6 led to improved photosynthesis and increased root growth when exposed to oxidative stress-inducing conditions [177]. SlCRF5, a tomato CRF6 orthologue, is also induced by heat, hydrogen peroxide and drought [178]. In addition, retrograde signaling in response to mitochondria dysfunction controls CRF6 and CRF5 expression $[179,180]$. Recently, Arabidopsis CRF6 was proposed as a component of the ROS-cytokinin crosstalk regulatory network, serving to attenuate cytokinin signaling as part of an adaptive response to stress. In response to hydrogen peroxide treatment, CRF6 represses the expression of genes involved in the cytokinin signaling pathway, which include $A H P 1$, type-A ARR6 and ARR9 and type-B ARR1. In addition, cytokinin biosynthesis LOG7 and cytokinin transport ABCG14 genes are also repressed by CRF6 [177]. Examination of Arabidopsis CRFs showed strong transcriptional induction of CRF4 in shoots and roots after exposure to cold. CRF4 overexpressors and loss-of-function crf4 plants exposed to cold stress showed no differences from untreated plants in term of stress tolerance. Upon exposure to freezing temperatures, however, a positive correlation between CRF4 expression levels and stress tolerance was observed [181]. Finally, ROS- and redox-responsive protein modification could sharpen hormone signals during stress acclimation responses since TIR1 and AHPs are targets of NO S-nitrosylation [182,183].

\section{Auxin-Cytokinin Crosstalk}

Given that the physiologic effects of auxin and cytokinin depend largely on their concentrations, mechanisms regulating their synthesis and breakdown are very important for different developmental processes. Besides, interactions between auxin and cytokinins operate extensively via reciprocal influences on each other's metabolism [184]. Evidently, crosstalk between these phytohormones also occurs via co-regulated genes and shared signaling components. In addition, the crosstalk is spatially and temporally regulated, providing thus adaptability and fine-tuning of responses. In recent years, crosstalk between the two hormones has been studied extensively at all levels: synthesis, perception and transport; and we are beginning to understand how these networks interact to control a wide variety of plant responses $[3,8,19,185-187]$. Here, we summarize current knowledge on auxin-cytokinin crosstalk pathways.

\subsection{Metabolism-Related Auxin-Cytokinin Crosstalk Components}

Auxin-mediated regulation of cytokinin synthesis was first observed in Arabidopsis roots treated with auxin, which led to upregulation of the IPT5 and IPT7 genes [188]. In the case of IPT5, upregulation by auxin is mediated by SHY2/IAA3 [189,190]. In shoots, in vivo deuterium incorporation experiments have shown that auxin mediates a very rapid negative control of the cytokinin pool mainly by suppressing the biosynthesis of $\mathrm{tZ}$ via the isopentenyladenosine- $5^{\prime}$-monophosphate iP nucleotide-independent pathway [191]. In addition to its role in cytokinin biosynthesis, auxin has also been shown to affect cytokinin degradation by downregulating $C K X 2, C K X 4$, and $C K X 7$ gene expression and upregulating CKX1 and CKX6 in Arabidopsis auxin-treated seedlings [192]. Moreover, the Arabidopsis CKX6 gene is rapidly and transiently induced by auxin during leaf development in canopy shade [193]. 
Elevated cytokinin levels lead to a rapid increase in auxin biosynthesis in young, developing root and leaf tissues, whereas decreased endogenous cytokinin levels reduce auxin biosynthesis in six days after germination in whole seedlings and root meristem tissues [194]. Analysis of auxin biosynthesis pathways revealed that in root meristems, enzymes from the tryptophan-dependent IAA biosynthesis pathway are regulated by cytokinin at transcriptional level. These activities include those of anthranilate synthase alpha subunit 1 (ASA1), anthranilate transferase 1 (PAT1), indole-3-glycerolphosphate synthase (IGPS), cytochrome P450s CYP79B2 and CYP79B3, YUC5, YUC6, YUC5-like, tryptophan aminotransferase (TAA1); as well as of enzymes from the indole-3-acetonitrile (IAN) pathway, nitrilase 1 (NIT1) and nitrilase 3 (NIT3), which catalyze the conversion of indole-3-acetonitrile (IAN) to IAA. In addition, auxin conjugation was also found to be affected by cytokinin via regulation of GH3.17 and GH3.9 expression [194].

Reduction of IAA levels in Arabidopsis aerial tissue was observed in six-leaf stage 35S::CKX1 and 35S::CKX2 seedlings [61]. On the other hand, expression of AtCKX3 in tobacco plants does not affect IAA content in leaves [195]. Therefore, contradictions regarding the reciprocal interplay between cytokinin and auxin rely on the fact that auxin-cytokinin crosstalk pathways are developmental stage dependent and tissue specific. For example, cytokinin and auxin interactions in OsCKX2 RNAi plants are observed through the reduction of IAA levels triggered by accumulation of $\mathrm{tZ}$-type cytokinins in the panicle region. The increased number of spikelets and hence grain yield in mutant plants indicates enhancement of inflorescence meristem activity due to a more favorable cytokinin-auxin ratio in this secondary meristem [76].

\subsection{Signaling-Related Auxin-Cytokinin Crosstalk Components}

The interaction of auxin and cytokinin signaling pathways is crucial in the control of shoot apical meristem activity and specification of embryonic roots. It has been shown that the negative regulators of the CK signaling pathway, the type-A ARR7 and ARR15, integrate cytokinin and auxin signals in the embryonic root, as well as in shoot-stem cell niche [196,197]. Auxin-controlled ARR7 and ARR15 activity is necessary for proper embryo development, and Arabidopsis embryos in which neither of the genes are functional show strong patterning defects [196]. In the shoot meristem, ARR7 and ARR15 expression is induced by cytokinin, whereas auxin has a negative effect. This is, at least in part, mediated by the AUXIN RESPONSE FACTOR5/MONOPTEROS (MP) transcription factor. These regulatory mechanisms confirm antagonism between auxin and cytokinin in the root meristem, even as they suggest a synergy between the two hormones in the shoot apical meristem, and this is well supported by classic shoot regeneration experiments [197]. In root apical meristems, interaction between auxin and cytokinin signaling pathways was also found to be mediated through Aux/IAA SHORT HYPOCOTYL2 (SHY2), a repressor of auxin signaling [189]. Thereby, ARR1 and ARR12 activate SHY2 transcription specifically at the vascular tissue of the transition zone of root meristem, which negatively regulates PIN1, PIN3 and PIN7 expression. Subsequent changes in auxin levels promote cell differentiation and lead to decrease in root apical meristem size [189,198]. Additionally, auxin-dependent degradation of SHY2 is required for the induction of ITP5 expression at the transition zone, as IPT5 activity is lost in the shy2-2 mutant [189]. Accordingly, it has been shown that cytokinin reduces auxin efflux from cultured tobacco cells [199], and it negatively regulates the expression of most of the PIN genes in roots $[189,199,200]$. An exception is seen in PIN7 expression, which is induced by cytokinin in Arabidopsis roots [136,200,201]. Besides a transcriptional regulation, cytokinin was found to regulate endocytic recycling of the auxin efflux carrier PIN1 by redirecting it for lytic degradation in vacuoles. Stimulation of the lytic PIN1 degradation is not a default effect for the general downregulation of proteins from plasma membranes, but rather it is a specific mechanism to rapidly modulate the auxin distribution in cytokinin-mediated developmental processes [200]. During lateral root initiation, for example, AHP6-dependant inhibition of cytokinin signaling allows the correct PIN1 localization and thus the formation of the auxin gradient required to pattern lateral root primordia [202]. 
Some cases of hormonal interactions to distinguish between primary, secondary or tertiary regulation are still not well understood [203]. Auxin-cytokinin crosstalk is spatially and temporally regulated, and interactions with other hormones must also be considered in order to understand developmental processes and responses to the environment fully. Further studies using genome-wide profiling for epigenetics, transcriptomics and proteomics will provide new information about the interconnected web of hormone actions.

\section{Abiotic Stress-Auxin-Cytokinin Transcriptional Crosstalk Networks}

As occurs with crops in the field, it is of pivotal importance to understand at the cellular and molecular levels how plant growth is adapted to a combination of environmental cues in order to design specifically tailored biotechnology tools. Previously, transcriptome analysis of the response of the complete set of genes involved in cytokinin signaling and metabolism to different environmental hardships showed that IPT3, IPT5, CYP735A2, LOG5, CKX4, ARR10 and CRF6 are the most responsive genes [204]. Here, we analyzed the response of the complete set of auxin and cytokinin pathway genes to different abiotic stress conditions, as well as to cytokinin and auxin treatments. To perform the analysis, we used gene expression data from Arabidopsis ecotypes Col-0, which are publicly available in the Genevestigator database [205]. We considered various kinds of abiotic stress: oxidative stress induced by exposure to high light (HL), heat, $\mathrm{H}_{2} \mathrm{O}_{2}$, or the ROS propagator methyl viologen (MV); osmotic stress imposed by exogenous addition of mannitol, polyethylene glycol or $\mathrm{NaCl}$; dehydration and drought. Auxin- and cytokinin-related genes simultaneously affected by both hormones and stressors were selected. It is also possible to compare their expression in different tissues such as roots, leaves and seedlings depending on the array experiments (Figure 1). These target genes could represent important auxin and cytokinin interaction hubs to control the dynamic behavior of cellular processes related to stress-induced reorientation of growth and thus relevant genetic tools to provide farmers with climate-resilient crops with improved yield and which mitigate unwanted morphological traits associated with stress. 




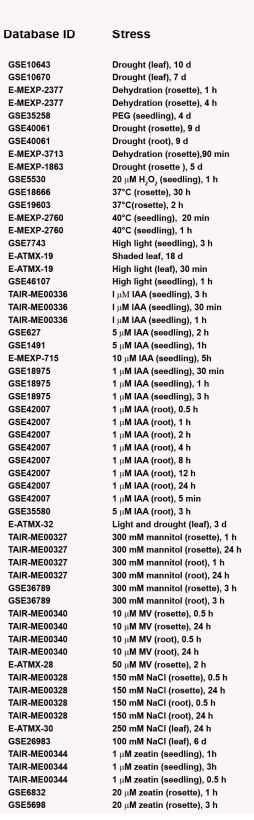



CYTOKININ

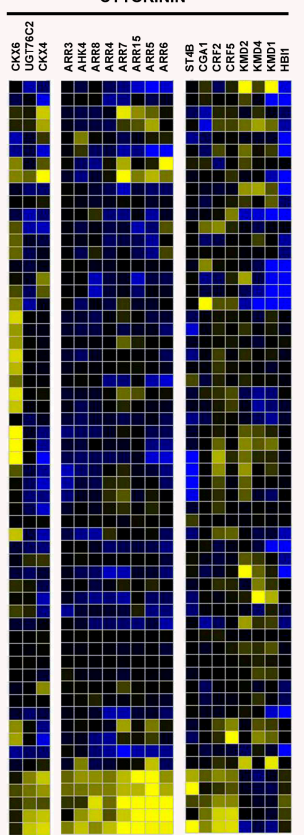

Figure 1. Auxin- and cytokinin-related genes differentially expressed by both hormones and various environmental cues. From 335 auxin- and 128 cytokinin-related genes selected from the literature and The Arabidopsis Information Resource (TAIR, Available online: www.arabidopsis.org), probes for 246 (auxin) and 128 (cytokinin) genes were found using the Genevestigator database and Affymetrix Arabidopsis ATH1 Genome Array (Available online: http://www.genevestigator.com/gv/ index.jsp). We analyzed their expression upon 59 perturbations from 328 microarrays. Using perturbation tool analysis and applying fold change cut-offs of $>1.5$ and significance $p$-values of $<0.05$, we ended up with a total of 36 auxin-related genes and 19 cytokinin-related genes that responded to both hormones and to single or multiple stressors at the same time. The figure shows the selected experiments, which can be retrieved using the unique database ID for each. The genes' expression responses are calculated as $\log _{2}$-ratios between the signal intensities from different perturbations as compared with control or mock-treated samples. (A) The panel shows a hierarchical clustering heat map from genes downregulated or upregulated simultaneously by all selected stresses. The hierarchical clustering maps for the total number of selected genes. (B) The panel shows the expression profile of auxin-related genes divided into 5 groups according to their roles (transport, metabolism, biosynthesis, signaling, and response genes) and 3 groups for cytokinin-related genes (metabolism, perception and signaling, and response-related genes). Gene expression patterns are represented in a $\log 2$ ratio ranging from -2.5 (blue color, down-regulated) to +2.5 (yellow color, up-regulated). Abbreviations: $\mathrm{d}=\mathrm{days}$; min $=$ minutes; $\mathrm{h}$ = hours; $\mathrm{PEG}=$ polyethylene glycol; $\mathrm{MV}=$ methyl viologen. 
In Figure 1A, genes displaying similar transcriptional response upon oxidative and osmotic stresses were grouped by hierarchical clustering analysis. Cluster 1 group genes downregulated by stress and induced by auxin and cytokinin treatments include the cytokinin-responsive basic helix-loop-helix HBI1, SAUR14, 15, 23 and 50, and auxin transporter PIN4. In addition, genes not responsive to $\mathrm{H}_{2} \mathrm{O}_{2}$ or methyl viologen (MV) treatments belonging to this cluster are the auxin response regulator IAA7, auxin transporters PIN7 and LAX3 and SAUR27, 64, 66 and 75. Cluster 2 is composed only of the auxin-inducible and glutathione (GSH)-dependent GLUTATHIONE S-TRANSFERASE TAU 5 (GSTU5) encoding gene, which is upregulated by all selected stressors. We hypothesize that these genes represent general components of the environmental stress response playing a crucial role in plant phenotype plasticity. In other words, they could constitute central components of the auxin-cytokinin regulatory transcriptional network, functioning as regulatory hubs between growth and stress-tolerance pathways. Supporting this hypothesis, for example, is the knowledge that PIN4- and PIN7-driven auxin transport is important for shaping shoot system architecture [206]. In Arabidopsis thaliana, Medicago truncatula and Lotus japonicas, active transport of auxin inside the cells carried out by LAX3 is important for lateral root emergence and the arrangement of leaves on a plant stem [207-209]. The contribution to auxin transport mediated by MtLAX3 may also play an important role during the processes of indirect somatic embryogenesis and symbiotic nodulation, and in both Medicago and Lotus, overexpression of LAX3 leads to increased leaf size, increased shoot branching, higher seed number and greater root nodulation [208]. SAURS are implicated in a wide range of developmental processes [210], and some from our analysis promote auxin-mediated control of plant cell elongation, including SAUR14, 15, 64, 66 and 75 [211], or cell expansion, as in the case of SAUR13 [212]. Downregulation of IAA7 in roots could be part of a stress-adaptive response, as repression of IAA7 in wheat roots by the transcription factor TaNAC69-1 increased root growth in drying soil [213]. Moreover, it is likely that HBI1 is a component of the central growth regulation circuit balancing growth and biotic stress responses [214].

Induction of GSTU5 gene expression by abiotic stresses is not surprising given its peroxidase activity. Accordingly, overexpression of tau-class GST with high glutathione peroxidase activity increases chilling, osmotic dehydration, salinity and herbicide tolerance in transgenic plants [215-219]. As the major non-protein thiol source, GSH precisely regulates cellular redox state in association with the ascorbate system, which in turn determines growth and developmental patterns in plants by modulating processes, such as mitosis, cell elongation, senescence, cell death and stress responses [28,220-222]. GSH redox state controlled by glutathione peroxidases, for example, plays an important role in root architecture and lateral root development [223]. Therefore, GST activities could be among the components linking auxin and redox signaling pathways through modulation of the cellular GSH redox buffer. The direct effect on growth and development of all these target genes is in line with the structural changes in plant tissues essential for adaptation to stress-prone environments.

On the other hand, genes showing stress- and tissue-specific regulation might represent fine-tuning components that assist or contribute to the necessary readjustment of auxin and cytokinin responses leading to altered growth and development in response to signals arising from specific environmental changes. A hierarchical clustering heat map of selected general and fine-tuning genes organized according to their role on auxin or cytokinin pathways is presented in Figure 1B. Fine-tuning genes for auxin transport include ABCB4, ABCB21, PILS3 and PILS5. The dual role of $A B C B$ transporters in polar auxin transport and stress tolerance [224] could be linked to their plasma membrane localization and their facultative auxin importers/exporters activity depending on auxin cytosolic levels. Moreover, the specificity of their actions depends on their tissue-specific expression patterns. $A B C B 21$ is highly expressed in junctions of lateral organs within the aerial part of plants and in pericycle cells of root tips [225]. Complementarily, $A B C B 4$ expression is restricted to root epidermis and cap [226]. The opposite expression pattern of PILS3 and PILS5 genes in drought-stressed leaves points to specific roles for their respective encoding proteins in intracellular auxin homeostasis. PILS5 reduces nuclear auxin signaling and stimulates auxin 
conjugation [227]. Hence, intracellular compartmentalization of IAA and IAA conjugates appears to contribute importantly to stress-dependent growth regulation. Regarding the auxin biosynthesis pathway, we selected YUC5 and NIT3 transcripts. Interestingly, both transcripts are induced by osmotic stressors, including mannitol and drought, thereby implicating both auxin biosynthesis genes in response to low water potential. NITs play an important role in glucosinolate metabolism and camalexin homeostasis, but their function in auxin biosynthesis is in doubt [228,229]. Disruption of the glucosinolate pathway leads to auxin-overproduction phenotypes, presumably due to diversion of intermediates to IAA synthesis via NITs [229]. Therefore, NITs' activities could indirectly regulate auxin levels under stress conditions by affecting the distribution of common auxin intermediates between YUC and glucosinolate pathways.

GH3.3, GH3.4 and WES1 transcripts, responsible for auxin homeostasis, are differentially expressed upon heat, mannitol, salt and drought treatments. GH3-mediated auxin homeostasis was proposed as a protective mechanism in response to excess of auxin [230]. In this sense, WES1 overexpression leads to smaller plants with severely dwarfed phenotype, which are more tolerant to cold, heat and drought [91].

Auxin signaling genes include a homeobox-leucine zipper gene HAT2 that is induced by auxin plus five IAAs. HAT2 plays opposing roles in roots and shoots in regulating auxin-mediated morphogenesis [231]. According to the expression pattern obtained for HAT2, it could play a role in growth modulation in the presence of stressors affecting water potential.

Auxin response-related genes differentially expressed upon stresses and both hormones include four SAURs (9, 55, 76, 79), AUXIN-INDUCED IN ROOT CULTURES 12 (AIR12), AUXIN-REGULATED GENE INVOLVED IN ORGAN SIZE (ARGOS), myb family transcription factor REVEILLE1 (RVE1) and ARABIDOPSIS THALIANA HOMEOBOX PROTEIN 2 (ATHB-2) genes. In accordance with the stress-specific regulation of the cell cycle [229], transcription of the positive regulator of cell proliferation ARGOS [232] is induced in roots under salt, mannitol or drought stress and in high light-stressed leaves, and it is repressed by heat stress in shoots. Supporting the stress adaptation role, constitutive overexpression of ARGOS genes leads to improved drought performance and also affects ethylene signaling in both Arabidopsis and maize plants [233]. The clock regulated transcription factor RVE1 promotes plant growth by regulating YUC8 gene expression during the day [234]. Therefore, RVE1 could work as a node that connects auxin and circadian signaling networks with the external environment to control plant growth accordingly.

Among cytokinin-related genes, transcript levels of CKX4 are particularly responsive to the environment, and CKX4 has been pointed out as one of the components of the cytokinin-stress regulatory network involved in root system architecture [204]. In line with the observed positive effect of reduced cytokinin levels in roots on plant growth and development upon stress [57], CKX6 transcripts are upregulated upon salt, mannitol and drought treatments in roots. High light also induced CKX6 expression, indicating that tissue specific compartmentalization of cytokinin degradation, as well as substrate preference of CKX isoforms define cytokinin signaling and stress tolerance. A regulator of cytokinin homeostasis, UGT76C2, is also present in our analysis. Its participation during heat and high light adaptation responses could be inferred through its transcriptional response, as already observed during drought and osmotic stress responses [99]. AHK2, AHK3 and AHK4 are considered to act as negative regulators of salt, drought $[159,168]$, rapid dehydration [168] and freeze tolerance [161]. However, only AHK4 responded against both hormones and abiotic stress (mannitol, high light and drought stresses). Therefore, it is reasonable to think that AHKs hand down specific effects depending on the type of stress and their tissue-specific expression pattern. That is in addition to the nature of the downstream AHPs and ARRs signaling pathway components that they regulate. Several type-A ARRs respond to osmotic stress, including drought, salinity and mannitol treatments. Interestingly, drought induction of ARR 5 and ARR15 is independent of the cytokinin receptors [168], implying stress-specific regulation of their transcription. 
Cytokinin response factors present in the analysis include CRF5, CRF2, CYTOKININ-RESPONSIVE GATA TRANSCRIPTION FACTOR1 (CGA1), KISS ME DEADLY (KMD) 1, 2 and 4 and the flavonoid glycoside 7-sulfotransferase (ST4B). The F-box proteins KMD1, KMD2 and KMD4 are negative regulators of the cytokinin-signaling cascade [235] and of antioxidant phenylpropanoid biosynthesis [236], suggesting their role as coordinators of both cytokinin and stress defense systems.

Even though the analysis has been made (1) using a pre-selection of well-characterized components of both hormonal routes and (2) only at the transcriptional level, its results augment the information about common target genes modulated by hormonal and stress circuits. Thereby, it can contribute to our understanding as to the molecular basis of plant phenotype flexibility in a changing climate.

\section{Conclusions}

In recent decades, the scientific community has independently accumulated an unprecedented amount of knowledge relating to the molecular and genetic mechanisms controlling the defense mechanisms plants use to survive sudden changes in their habitats and the physiological and developmental processes directed by phytohormones. Nevertheless, it is only in recent years that the importance of integrating the two processes has become evident, inasmuch as, in addition to interacting with one another, stress and phytohormone modules also share common components. These components belong to complex signaling networks that prevent or attenuate cellular damage upon stress by affecting plant growth and development. As a result, plants accordingly adapt their morphology to their new imposed habitat.

In this review, we aimed to provide an overview of the molecular targets that balance auxin and cytokinin homeostasis and interact with signals triggered by plant cells under unfavorable growth conditions. The increasing amount of molecular data contributes to broadening our knowledge on auxin-cytokinin crosstalk in its developmental aspects and, at the same time, introduces an additional level of complexity. In this sense, additional crosstalk mechanisms of both with other plant hormones in stress-induced growth regulation contribute to the large pleiotropy in auxin and cytokinin actions.

Future research employing computational tools for the integration of genome-scale mathematical modeling in systems biology, field and laboratory growth and development experiments and large-scale mutational analyses are pivotal to forming a deeper understanding of plant growth and development in response to environmental cues.

Thus, the intra- and inter-cellular spatial and temporal distribution of ROS and phytohormones among plant tissues and organs could represent an attractive manipulation platform for boosting crop yields.

Supplementary Materials: Supplementary materials can be found at www.mdpi.com/1422-0067/18/7/1427/s1.

Acknowledgments: This work was supported by grants from the ROS-auxin (333844), FP7-People-Marie Curie actions-CIG, 2013-2017, the Czech Science Foundation (GA15-16520S; GA15-18005Y) and the Ministry of Education, Youth and Sports of the Czech Republic under the project CEITEC 2020 (LQ1601). The authors would like to thank Helene Robert Boisivon, CEITEC, for critically reading the manuscript.

Author Contributions: Agnieszka Bielach and Vanesa B. Tognetti contributed equally in writing the review; Vanesa B. Tognetti performed the transcriptional analysis and edited the text; Agnieszka Bielach compiled and organized the data shown in the Supplementary Table; Monika Hrtyan participated in preparation of the manuscript, formatting and editing of the text.

Conflicts of Interest: The authors declare no conflict of interest.

\section{References}

1. Skoog, F.; Miller, C.O. Chemical regulation of growth and organ formation in plant tissues cultured in vitro. Symp. Soc. Exp. Biol. 1957, 54, 118-130.

2. Benjamins, R.; Scheres, B. Auxin: The Looping Star in Plant Development. Annu. Rev. Plant Biol. 2008, 59, 443-465. [CrossRef] [PubMed] 
3. Chandler, J.W.; Werr, W. Cytokinin-auxin crosstalk in cell type specification. Trends Plant Sci. 2015, 20, 291-300. [CrossRef] [PubMed]

4. Del Bianco, M.; Giustini, L.; Sabatini, S. Spatiotemporal changes in the role of cytokinin during root development. New Phytol. 2013, 199, 324-338. [CrossRef] [PubMed]

5. Muller, D.; Leyser, O. Auxin, cytokinin and the control of shoot branching. Ann. Bot. 2011, 107, $1203-1212$. [CrossRef] [PubMed]

6. Robert, H.S.; Crhak Khaitova, L.; Mroue, S.; Benková, E. The importance of localized auxin production for morphogenesis of reproductive organs and embryos in Arabidopsis. J. Exp. Bot. 2015, 66, 5029-5042. [CrossRef] [PubMed]

7. Saini, S.; Sharma, I.; Kaur, N.; Pati, P.K. Auxin: A master regulator in plant root development. Plant Cell Rep. 2013, 32, 741-757. [CrossRef] [PubMed]

8. Schaller, G.E.; Bishopp, A.; Kieber, J.J. The yin-yang of hormones: Cytokinin and auxin interactions in plant development. Plant Cell 2015, 27, 44-63. [CrossRef] [PubMed]

9. Skylar, A.; Wu, X. Regulation of Meristem Size by Cytokinin Signaling. J. Integr. Plant Biol. 2011, 53, $446-454$. [CrossRef] [PubMed]

10. Taylor-Teeples, M.; Lanctot, A.; Nemhauser, J.L. As above, so below: Auxin's role in lateral organ development. Dev. Biol. 2016, 419, 156-164. [CrossRef] [PubMed]

11. Werner, T.; Schmülling, T. Cytokinin action in plant development. Curr. Opin. Plant Biol. 2009, 12, 527-538. [CrossRef] [PubMed]

12. Adamowski, M.; Friml, J. PIN-Dependent Auxin Transport: Action, Regulation, and Evolution. Plant Cell 2015, 27, 20-32. [CrossRef] [PubMed]

13. Argueso, C.T.; Raines, T.; Kieber, J.J. Cytokinin signaling and transcriptional networks. Curr. Opin. Plant Biol. 2010, 13, 533-539. [CrossRef] [PubMed]

14. Bennett, T. PIN proteins and the evolution of plant development. Trends Plant Sci. 2015, 20, 498-507. [CrossRef] [PubMed]

15. Hwang, I.; Sheen, J.; Müller, B. Cytokinin Signaling Networks. Annu. Rev. Plant Biol. 2012, 63, $353-380$. [CrossRef] [PubMed]

16. Kasahara, H. Current aspects of auxin biosynthesis in plants. Biosci. Biotechnol. Biochem. 2016, 80, 34-42. [CrossRef] [PubMed]

17. Pan, X.; Chen, J.; Yang, Z. Auxin regulation of cell polarity in plants. Curr. Opin. Plant Biol. 2015, 28, $144-153$. [CrossRef] [PubMed]

18. Kieber, J.J.; Schaller, G.E. Cytokinins. Arabidopsis Book Am. Soc. Plant Biol. 2014, 12, e0168. [CrossRef] [PubMed]

19. El-Showk, S.; Ruonala, R.; Helariutta, Y. Crossing paths: Cytokinin signalling and crosstalk. Development 2013, 140, 1373-1383. [CrossRef] [PubMed]

20. Sehra, B.; Franks, R.G. Auxin and cytokinin act during gynoecial patterning and the development of ovules from the meristematic medial domain. Wiley Interdiscip. Rev. Dev. Biol. 2015, 4, 555-571. [CrossRef] [PubMed]

21. Su, Y.-H.; Liu, Y.-B.; Zhang, X.-S. Auxin-cytokinin interaction regulates meristem development. Mol. Plant 2011, 4, 616-625. [CrossRef] [PubMed]

22. Vanstraelen, M.; Benková, E. Hormonal Interactions in the Regulation of Plant Development. Annu. Rev. Cell Dev. Biol. 2012, 28, 463-487. [CrossRef] [PubMed]

23. Mittler, R.; Vanderauwera, S.; Suzuki, N.; Miller, G.; Tognetti, V.B.; Vandepoele, K.; Gollery, M.; Shulaev, V.; Van Breusegem, F. ROS signaling: The new wave? Trends Plant Sci. 2011, 16, 300-309. [CrossRef] [PubMed]

24. Tognetti, V.B.; Mühlenbock, P.; Van Breusegem, F. Stress homeostasis-The redox and auxin perspective. Plant Cell Environ. 2012, 35, 321-333. [CrossRef] [PubMed]

25. Kazan, K. Auxin and the integration of environmental signals into plant root development. Ann. Bot. 2013, 112, 1655-1665. [CrossRef] [PubMed]

26. Krishnamurthy, A.; Rathinasabapathi, B. Auxin and its transport play a role in plant tolerance to arsenite-induced oxidative stress in Arabidopsis thaliana. Plant Cell Environ. 2013, 36, 1838-1849. [CrossRef] [PubMed]

27. O’Brien, J.A.; Benkova, E. Cytokinin cross-talking during biotic and abiotic stress responses. Front. Plant Sci. 2013, 4, 451. [CrossRef] [PubMed] 
28. Xia, X.-J.; Zhou, Y.-H.; Shi, K.; Zhou, J.; Foyer, C.H.; Yu, J.-Q. Interplay between reactive oxygen species and hormones in the control of plant development and stress tolerance. J. Exp. Bot. 2015, 66, 2839-2856. [CrossRef] [PubMed]

29. Zwack, P.J.; Rashotte, A.M. Interactions between cytokinin signalling and abiotic stress responses. J. Exp. Bot. 2015, 66, 4863-4871. [CrossRef] [PubMed]

30. Verma, V.; Ravindran, P.; Kumar, P.P. Plant hormone-mediated regulation of stress responses. BMC Plant Biol. 2016, 16, 86. [CrossRef] [PubMed]

31. Cerny, M.; Kuklova, A.; Hoehenwarter, W.; Fragner, L.; Novak, O.; Rotkova, G.; Jedelsky, P.L.; Zakova, K.; Smehilova, M.; Strnad, M.; et al. Proteome and metabolome profiling of cytokinin action in Arabidopsis identifying both distinct and similar responses to cytokinin down- and up-regulation. J. Exp. Bot. 2013, 64, 4193-4206. [CrossRef] [PubMed]

32. Ljung, K.; Bhalerao, R.P.; Sandberg, G. Sites and homeostatic control of auxin biosynthesis in Arabidopsis during vegetative growth. Plant J. 2001, 28, 465-474. [CrossRef] [PubMed]

33. Mühlenbock, P.; Szechyńska-Hebda, M.; Płaszczyca, M.; Baudo, M.; Mateo, A.; Mullineaux, P.M.; Parker, J.E.; Karpińska, B.; Karpiński, S. Chloroplast Signaling and LESION SIMULATING DISEASE1 Regulate Crosstalk between Light Acclimation and Immunity in Arabidopsis. Plant Cell Online 2008, 20, 2339-2356. [CrossRef] [PubMed]

34. Kim, J.I.; Baek, D.; Park, H.C.; Chun, H.J.; Oh, D.-H.; Lee, M.K.; Cha, J.-Y.; Kim, W.-Y.; Kim, M.C.; Chung, W.S.; et al. Overexpression of Arabidopsis YUCCA6 in potato results in high-auxin developmental phenotypes and enhanced resistance to water deficit. Mol. Plant 2013, 6, 337-349. [CrossRef] [PubMed]

35. Lee, M.; Jung, J.-H.; Han, D.-Y.; Seo, P.J.; Park, W.J.; Park, C.-M. Activation of a flavin monooxygenase gene YUCCA7 enhances drought resistance in Arabidopsis. Planta 2012, 235, 923-938. [CrossRef] [PubMed]

36. Park, H.C.; Cha, J.-Y.; Yun, D.-J. Roles of YUCCAs in auxin biosynthesis and drought stress responses in plants. Plant Signal. Behav. 2013, 8, e24495. [CrossRef] [PubMed]

37. Cheng, Y. Auxin biosynthesis by the YUCCA flavin monooxygenases controls the formation of floral organs and vascular tissues in Arabidopsis. Genes Dev. 2006, 20, 1790-1799. [CrossRef] [PubMed]

38. Sakata, T.; Oshino, T.; Miura, S.; Tomabechi, M.; Tsunaga, Y.; Higashitani, N.; Miyazawa, Y.; Takahashi, H.; Watanabe, M.; Higashitani, A. Auxins reverse plant male sterility caused by high temperatures. Proc. Natl. Acad. Sci. USA 2010, 107, 8569-8574. [CrossRef] [PubMed]

39. Cha, J.-Y.; Kim, W.-Y.; Kang, S.B.; Kim, J.I.; Baek, D.; Jung, I.J.; Kim, M.R.; Li, N.; Kim, H.-J.; Nakajima, M.; et al. A novel thiol-reductase activity of Arabidopsis YUC6 confers drought tolerance independently of auxin biosynthesis. Nat. Commun. 2015, 6, 8041. [CrossRef] [PubMed]

40. Ke, Q.; Wang, Z.; Ji, C.Y.; Jeong, J.C.; Lee, H.-S.; Li, H.; Xu, B.; Deng, X.; Kwak, S.-S. Transgenic poplar expressing Arabidopsis YUCCA6 exhibits auxin-overproduction phenotypes and increased tolerance to abiotic stress. Plant Physiol. Biochem. 2015, 94, 19-27. [CrossRef] [PubMed]

41. Shi, H.; Chen, L.; Ye, T.; Liu, X.; Ding, K.; Chan, Z. Modulation of auxin content in Arabidopsis confers improved drought stress resistance. Plant Physiol. Biochem. 2014, 82, 209-217. [CrossRef] [PubMed]

42. Woo, Y.-M.; Park, H.-J.; Su'udi, M.; Yang, J.-I.; Park, J.-J.; Back, K.; Park, Y.-M.; An, G. Constitutively wilted 1, a member of the rice YUCCA gene family, is required for maintaining water homeostasis and an appropriate root to shoot ratio. Plant Mol. Biol. 2007, 65, 125-136. [CrossRef] [PubMed]

43. Werner, T.; Nehnevajova, E.; Kollmer, I.; Novak, O.; Strnad, M.; Kramer, U.; Schmulling, T. Root-Specific Reduction of Cytokinin Causes Enhanced Root Growth, Drought Tolerance, and Leaf Mineral Enrichment in Arabidopsis and Tobacco. Plant Cell 2010, 22, 3905-3920. [CrossRef] [PubMed]

44. Mok, D.W.; Mok, M.C. Cytokinin Metabolism and Action. Annu. Rev. Plant Physiol. Plant Mol. Biol. 2001, 52, 89-118. [CrossRef] [PubMed]

45. Sakakibara, H. Cytokinins: Activity, biosynthesis, and translocation. Annu. Rev. Plant Biol. 2006, 57, 431-449. [CrossRef] [PubMed]

46. Frebort, I.; Kowalska, M.; Hluska, T.; Frebortova, J.; Galuszka, P. Evolution of cytokinin biosynthesis and degradation. J. Exp. Bot. 2011, 62, 2431-2452. [CrossRef] [PubMed]

47. Hare, P.D.; Cress, W.A.; van Staden, J. The involvement of cytokinins in plant responses to environmental stress. Plant Growth Regul. 1997, 23, 79-103. [CrossRef]

48. Argueso, C.T.; Ferreira, F.J.; Kieber, J.J. Environmental perception avenues: The interaction of cytokinin and environmental response pathways. Plant Cell Environ. 2009, 32, 1147-1160. [CrossRef] [PubMed] 
49. Bano, A.; Hansen, H.; Dörffling, K.; Hahn, H. Changes in the contents of free and conjugated abscisic acid, phaseic acid and cytokinins in xylem sap of drought stressed sunflower plants. Phytochemistry 1994, 37, 345-347. [CrossRef]

50. Shashidhar, V.R.; Prasad, T.G.; Sudharshan, L. Hormone signals from roots to shoots of sunflower (Helianthus annuus L.). Moderate soil drying increases delivery of abscisic acid and depresses delivery of cytokinins in xylem sap. Ann. Bot. 1996, 78, 151-155. [CrossRef]

51. Alvarez, S.; Marsh, E.L.; Schroeder, S.G.; Schachtman, D.P. Metabolomic and proteomic changes in the xylem sap of maize under drought. Plant Cell Environ. 2008, 31, 325-340. [CrossRef] [PubMed]

52. Davies, W.J.; Kudoyarova, G.; Hartung, W. Long-distance ABA Signaling and Its Relation to Other Signaling Pathways in the Detection of Soil Drying and the Mediation of the Plant's Response to Drought. J. Plant Growth Regul. 2005, 24, 285-295. [CrossRef]

53. Hansen, H.; Dörffling, K. Root-derived trans-zeatin riboside and abscisic acid in drought-stressed and rewatered sunflower plants: Interaction in the control of leaf diffusive resistance? Funct. Plant Biol. 2003, 30, 365-375. [CrossRef]

54. McDAVID, C.R.; Sagar, G.R.; Marshall, C. The Effect of Root Pruning and 6-Benzyl-Aminopurine on the Chlorophyll Content, ${ }^{14} \mathrm{CO}_{2}$ Fixation and the Shoot/Root Ratio in Seedlings of Pisvm Sativum L. New Phytol. 1973, 72, 465-470. [CrossRef]

55. Thomas, J.C.; McElwain, E.F.; Bohnert, H.J. Convergent Induction of Osmotic Stress-Responses 1. Plant Physiol. 1992, 100, 416-423. [CrossRef] [PubMed]

56. Lubovská, Z.; Dobrá, J.; Štorchová, H.; Wilhelmová, N.; Vanková, R. Cytokinin oxidase/dehydrogenase overexpression modifies antioxidant defense against heat, drought and their combination in Nicotiana tabacum plants. J. Plant Physiol. 2014, 171, 1625-1633. [CrossRef] [PubMed]

57. Mackova, H.; Hronkova, M.; Dobra, J.; Tureckova, V.; Novak, O.; Lubovska, Z.; Motyka, V.; Haisel, D.; Hajek, T.; Prasil, I.T.; et al. Enhanced drought and heat stress tolerance of tobacco plants with ectopically enhanced cytokinin oxidase/dehydrogenase gene expression. J. Exp. Bot. 2013, 64, 2805-2815. [CrossRef] [PubMed]

58. Nishiyama, R.; Watanabe, Y.; Fujita, Y.; Le, D.T.; Kojima, M.; Werner, T.; Vankova, R.; Yamaguchi-Shinozaki, K.; Shinozaki, K.; Kakimoto, T.; et al. Analysis of Cytokinin Mutants and Regulation of Cytokinin Metabolic Genes Reveals Important Regulatory Roles of Cytokinins in Drought, Salt and Abscisic Acid Responses, and Abscisic Acid Biosynthesis. Plant Cell 2011, 23, 2169-2183. [CrossRef] [PubMed]

59. Pospíšilová, H.; Jiskrová, E.; Vojta, P.; Mrízová, K.; Kokáš, F.; Čudejková, M.M.; Bergougnoux, V.; Plíhal, O.; Klimešová, J.; Novák, O.; et al. Transgenic barley overexpressing a cytokinin dehydrogenase gene shows greater tolerance to drought stress. New Biotechnol. 2016, 33, 692-705. [CrossRef] [PubMed]

60. Vojta, P.; Kokáš, F.; Husičková, A.; Grúz, J.; Bergougnoux, V.; Marchetti, C.F.; Jiskrová, E.; Ježilová, E.; Mik, V.; Ikeda, Y.; et al. Whole transcriptome analysis of transgenic barley with altered cytokinin homeostasis and increased tolerance to drought stress. New Biotechnol. 2016, 33, 676-691. [CrossRef] [PubMed]

61. Werner, T.; Motyka, V.; Laucou, V.; Smets, R.; Van Onckelen, H.; Schmulling, T. Cytokinin-Deficient Transgenic Arabidopsis Plants Show Multiple Developmental Alterations Indicating Opposite Functions of Cytokinins in the Regulation of Shoot and Root Meristem Activity. Plant Cell 2003, 15, 2532-2550. [CrossRef] [PubMed]

62. Rivero, R.M.; Gimeno, J.; Deynze, A.V.; Walia, H.; Blumwald, E. Enhanced Cytokinin Synthesis in Tobacco Plants Expressing PSARK::IPT Prevents the Degradation of Photosynthetic Protein Complexes During Drought. Plant Cell Physiol. 2010, 51, 1929-1941. [CrossRef] [PubMed]

63. Peleg, Z.; Reguera, M.; Tumimbang, E.; Walia, H.; Blumwald, E. Cytokinin-mediated source/sink modifications improve drought tolerance and increase grain yield in rice under water-stress. Plant Biotechnol. J. 2011, 9, 747-758. [CrossRef] [PubMed]

64. Qin, H.; Gu, Q.; Zhang, J.; Sun, L.; Kuppu, S.; Zhang, Y.; Burow, M.; Payton, P.; Blumwald, E.; Zhang, H. Regulated Expression of an Isopentenyltransferase Gene (IPT) in Peanut Significantly Improves Drought Tolerance and Increases Yield Under Field Conditions. Plant Cell Physiol. 2011, 52, 1904-1914. [CrossRef] [PubMed]

65. Kuppu, S.; Mishra, N.; Hu, R.; Sun, L.; Zhu, X.; Shen, G.; Blumwald, E.; Payton, P.; Zhang, H. Water-Deficit Inducible Expression of a Cytokinin Biosynthetic Gene IPT Improves Drought Tolerance in Cotton. PLoS ONE 2013, 8, e64190. [CrossRef] [PubMed] 
66. Décima Oneto, C.; Otegui, M.E.; Baroli, I.; Beznec, A.; Faccio, P.; Bossio, E.; Blumwald, E.; Lewi, D. Water deficit stress tolerance in maize conferred by expression of an isopentenyltransferase (IPT) gene driven by a stress- and maturation-induced promoter. J. Biotechnol. 2016, 220, 66-77. [CrossRef] [PubMed]

67. Rivero, R. M.; Kojima, M.; Gepstein, A.; Sakakibara, H.; Mittler, R.; Gepstein, S.; Blumwald, E. Delayed leaf senescence induces extreme drought tolerance in a flowering plant. Proc. Natl. Acad. Sci. USA 2007, 104, 19631-19636. [CrossRef] [PubMed]

68. Merewitz, E.B.; Gianfagna, T.; Huang, B. Photosynthesis, water use, and root viability under water stress as affected by expression of SAG12-ipt controlling cytokinin synthesis in Agrostis stolonifera. J. Exp. Bot. 2011, 62, 383-395. [CrossRef] [PubMed]

69. Xu, Y.; Burgess, P.; Zhang, X.; Huang, B. Enhancing cytokinin synthesis by overexpressing ipt alleviated drought inhibition of root growth through activating ROS-scavenging systems in Agrostis stolonifera. J. Exp. Bot. 2016, 67, 1979-1992. [CrossRef] [PubMed]

70. Wang, Y.; Shen, W.; Chan, Z.; Wu, Y. Endogenous Cytokinin Overproduction Modulates ROS Homeostasis and Decreases Salt Stress Resistance in Arabidopsis Thaliana. Front. Plant Sci. 2015, 6, 1004. [CrossRef] [PubMed]

71. Žižková, E.; Dobrev, P.I.; Muhovski, Y.; Hošek, P.; Hoyerová, K.; Haisel, D.; Procházková, D.; Lutts, S.; Motyka, V.; Hichri, I. Tomato (Solanum lycopersicum L.) SIIPT3 and SIIPT4 isopentenyltransferases mediate salt stress response in tomato. BMC Plant Biol. 2015. [CrossRef]

72. Tognetti, V.B.; Van Aken, O.; Morreel, K.; Vandenbroucke, K.; van de Cotte, B.; De Clercq, I.; Chiwocha, S.; Fenske, R.; Prinsen, E.; Boerjan, W.; et al. Perturbation of indole-3-butyric acid homeostasis by the UDP-glucosyltransferase UGT74E2 modulates Arabidopsis architecture and water stress tolerance. Plant Cell 2010, 22, 2660-2679. [CrossRef] [PubMed]

73. Maruyama, K.; Urano, K.; Yoshiwara, K.; Morishita, Y.; Sakurai, N.; Suzuki, H.; Kojima, M.; Sakakibara, H.; Shibata, D.; Saito, K.; et al. Integrated analysis of the effects of cold and dehydration on rice metabolites, phytohormones, and gene transcripts. Plant Physiol. 2014, 164, 1759-1771. [CrossRef] [PubMed]

74. Tripathi, A.K.; Pareek, A.; Sopory, S.K.; Singla-Pareek, S.L. Narrowing down the targets for yield improvement in rice under normal and abiotic stress conditions via expression profiling of yield-related genes. Rice N. Y. 2012, 5, 37. [CrossRef] [PubMed]

75. Wu, C.; Cui, K.; Wang, W.; Li, Q.; Fahad, S.; Hu, Q.; Huang, J.; Nie, L.; Mohapatra, P.K.; Peng, S. Heat-Induced Cytokinin Transportation and Degradation Are Associated with Reduced Panicle Cytokinin Expression and Fewer Spikelets per Panicle in Rice. Front. Plant Sci. 2017, 8, 371. [CrossRef] [PubMed]

76. Joshi, R.; Sahoo, K.K.; Tripathi, A.K.; Kumar, R.; Gupta, B.K.; Pareek, A.; Singla-Pareek, S.L. TKnockdown of an inflorescence meristem-specific cytokinin oxidase-OsCKX2 in rice reduces yield penalty under salinity stress condition. Plant Cell Environ. 2017. [CrossRef] [PubMed]

77. Chang, Z.; Liu, Y.; Dong, H.; Teng, K.; Han, L.; Zhang, X. Effects of Cytokinin and Nitrogen on Drought Tolerance of Creeping Bentgrass. PLoS ONE 2016, 11, e0154005. [CrossRef] [PubMed]

78. Liu, X.; Huang, B. Cytokinin Effects on Creeping Bentgrass Response to Heat Stress. Crop Sci. 2002, 42, 466-472. [CrossRef]

79. Mýtinová, Z.; Motyka, V.; Haisel, D.; Gaudinová, A.; Lubovská, Z.; Wilhelmová, N. Effect of abiotic stresses on the activity of antioxidative enzymes and contents of phytohormones in wild type and AtCKX2 transgenic tobacco plants. Biol. Plant. 2010, 54, 461-470. [CrossRef]

80. Skalák, J.; Černý, M.; Jedelský, P.; Dobrá, J.; Ge, E.; Novák, J.; Hronková, M.; Dobrev, P.; Vanková, R.; Brzobohatý, B. Stimulation of ipt overexpression as a tool to elucidate the role of cytokinins in high temperature responses of Arabidopsis thaliana. J. Exp. Bot. 2016, 67, 2861-2873. [CrossRef] [PubMed]

81. Zavaleta-Mancera, H.A.; López-Delgado, H.; Loza-Tavera, H.; Mora-Herrera, M.; Trevilla-García, C.; Vargas-Suárez, M.; Ougham, H. Cytokinin promotes catalase and ascorbate peroxidase activities and preserves the chloroplast integrity during dark-senescence. J. Plant Physiol. 2007, 164, 1572-1582. [CrossRef] [PubMed]

82. Kawano, T. Roles of the reactive oxygen species-generating peroxidase reactions in plant defense and growth induction. Plant Cell Rep. 2003, 21, 829-837. [PubMed]

83. Jansen, M.A.K.; van den Noort, R.E.; Tan, M.Y.A.; Prinsen, E.; Lagrimini, L.M.; Thorneley, R.N.F. Phenol-Oxidizing Peroxidases Contribute to the Protection of Plants from Ultraviolet Radiation Stress. Plant Physiol. 2001, 126, 1012-1023. [CrossRef] [PubMed] 
84. Vatulescu, A.D.; Fortunato, A.S.; Sá, M.C.; Amâncio, S.; Ricardo, C.P.P.; Jackson, P.A. Cloning and characterisation of a basic IAA oxidase associated with root induction in Vitis vinifera. Plant Physiol. Biochem. 2004, 42, 609-615. [CrossRef] [PubMed]

85. Cosio, C.; Vuillemin, L.; Meyer, M.D.; Kevers, C.; Penel, C.; Dunand, C. An anionic class III peroxidase from zucchini may regulate hypocotyl elongation through its auxin oxidase activity. Planta 2009, 229, 823-836. [CrossRef] [PubMed]

86. Potters, G.; Pasternak, T.P.; Guisez, Y.; Jansen, M.A.K. Different stresses, similar morphogenic responses: integrating a plethora of pathways. Plant Cell Environ. 2009, 32, 158-169. [CrossRef] [PubMed]

87. Vanderauwera, S.; Zimmermann, P.; Rombauts, S.; Vandenabeele, S.; Langebartels, C.; Gruissem, W.; Inze, D.; Van Breusegem, F. Genome-Wide Analysis of Hydrogen Peroxide-Regulated Gene Expression in Arabidopsis Reveals a High Light-Induced Transcriptional Cluster Involved in Anthocyanin Biosynthesis. Plant Physiol. 2005, 139, 806-821. [CrossRef] [PubMed]

88. Ahrazem, O.; Rubio-Moraga, A.; Trapero-Mozos, A.; Climent, M.F.L.; Gómez-Cadenas, A.; Gómez-Gómez, L. Ectopic expression of a stress-inducible glycosyltransferase from saffron enhances salt and oxidative stress tolerance in Arabidopsis while alters anchor root formation. Plant Sci. 2015, 234, 60-73. [CrossRef] [PubMed]

89. Ludwig-Müller, J. Auxin conjugates: Their role for plant development and in the evolution of land plants. J. Exp. Bot. 2011, 62, 1757-1773. [CrossRef] [PubMed]

90. Du, H.; Wu, N.; Fu, J.; Wang, S.; Li, X.; Xiao, J.; Xiong, L. A GH3 family member, OsGH3-2, modulates auxin and abscisic acid levels and differentially affects drought and cold tolerance in rice. J. Exp. Bot. 2012, 63, 6467-6480. [CrossRef] [PubMed]

91. Park, J.-E.; Park, J.-Y.; Kim, Y.-S.; Staswick, P.E.; Jeon, J.; Yun, J.; Kim, S.-Y.; Kim, J.; Lee, Y.-H.; Park, C.-M. GH3-mediated Auxin Homeostasis Links Growth Regulation with Stress Adaptation Response in Arabidopsis. J. Biol. Chem. 2007, 282, 10036-10046. [CrossRef] [PubMed]

92. Teichmann, T.; Bolu-Arianto, W.H.; Olbrich, A.; Langenfeld-Heyser, R.; Göbel, C.; Grzeganek, P.; Feussner, I.; Hänsch, R.; Polle, A. GH3::GUS reflects cell-specific developmental patterns and stress-induced changes in wood anatomy in the poplar stem. Tree Physiol. 2008, 28, 1305-1315. [CrossRef] [PubMed]

93. Zhang, S.-W.; Li, C.-H.; Cao, J.; Zhang, Y.-C.; Zhang, S.-Q.; Xia, Y.-F.; Sun, D.-Y.; Sun, Y. Altered Architecture and Enhanced Drought Tolerance in Rice via the Down-Regulation of Indole-3-Acetic Acid by TLD1/OsGH3.13 Activation. Plant Physiol. 2009, 151, 1889-1901. [CrossRef] [PubMed]

94. Junghans, U.; Polle, A.; Düchting, P.; Weiler, E.; Kuhlman, B.; Gruber, F.; Teichmann, T. Adaptation to high salinity in poplar involves changes in xylem anatomy and auxin physiology. Plant Cell Environ. 2006, 29, 1519-1531. [CrossRef] [PubMed]

95. Singh, V.K.; Jain, M.; Garg, R. Genome-wide analysis and expression profiling suggest diverse roles of GH3 genes during development and abiotic stress responses in legumes. Front. Plant Sci. 2015. [CrossRef] [PubMed]

96. Feng, S.; Yue, R.; Tao, S.; Yang, Y.; Zhang, L.; Xu, M.; Wang, H.; Shen, C. Genome-wide identification, expression analysis of auxin-responsive GH3 family genes in maize (Zea mays L.) under abiotic stresses. J. Integr. Plant Biol. 2015, 57, 783-795. [CrossRef] [PubMed]

97. Kinoshita, N.; Wang, H.; Kasahara, H.; Liu, J.; MacPherson, C.; Machida, Y.; Kamiya, Y.; Hannah, M.A.; Chua, N.-H. IAA-Ala Resistant3, an Evolutionarily Conserved Target of miR167, Mediates Arabidopsis Root Architecture Changes during High Osmotic Stress. Plant Cell 2012, 24, 3590-3602. [CrossRef] [PubMed]

98. Ostrowski, M.; Ciarkowska, A.; Jakubowska, A. The auxin conjugate indole-3-acetyl-aspartate affects responses to cadmium and salt stress in Pisum sativum L. J. Plant Physiol. 2016, 191, 63-72. [CrossRef] [PubMed]

99. Li, Y.; Wang, B.; Dong, R.; Hou, B. AtUGT76C2, an Arabidopsis cytokinin glycosyltransferase is involved in drought stress adaptation. Plant Sci. 2015, 236, 157-167. [CrossRef] [PubMed]

100. Gidrol, X.; Lin, W.S.; Dégousée, N.; Yip, S.F.; Kush, A. Accumulation of Reactive Oxygen Species and Oxidation of Cytokinin in Germinating Soybean Seeds. Eur. J. Biochem. 1994, 224, 21-28. [CrossRef] [PubMed]

101. Peer, W.A.; Cheng, Y.; Murphy, A.S. Evidence of oxidative attenuation of auxin signalling. J. Exp. Bot. 2013, 64, 2629-2639. [CrossRef] [PubMed]

102. Peer, W.A.; Murphy, A.S. Flavonoids and auxin transport: Modulators or regulators? Trends Plant Sci. 2007, 12, 556-563. [CrossRef] [PubMed] 
103. Santelia, D.; Henrichs, S.; Vincenzetti, V.; Sauer, M.; Bigler, L.; Klein, M.; Bailly, A.; Lee, Y.; Friml, J.; Geisler, M.; et al. Flavonoids Redirect PIN-mediated Polar Auxin Fluxes during Root Gravitropic Responses. J. Biol. Chem. 2008, 283, 31218-31226. [CrossRef] [PubMed]

104. Kuhn, B.M.; Geisler, M.; Bigler, L.; Ringli, C. Flavonols Accumulate Asymmetrically and Affect Auxin Transport in Arabidopsis. Plant Physiol. 2011, 156, 585-595. [CrossRef] [PubMed]

105. Agati, G.; Brunetti, C.; Di Ferdinando, M.; Ferrini, F.; Pollastri, S.; Tattini, M. Functional roles of flavonoids in photoprotection: New evidence, lessons from the past. Plant Physiol. Biochem. 2013, 72, 35-45. [CrossRef] [PubMed]

106. Brown, D.E.; Rashotte, A.M.; Murphy, A.S.; Normanly, J.; Tague, B.W.; Peer, W.A.; Taiz, L.; Muday, G.K. Flavonoids act as negative regulators of auxin transport in vivo in arabidopsis. Plant Physiol. 2001, 126, 524-535. [CrossRef] [PubMed]

107. Buer, C.S.; Muday, G.K. The transparent testa 4 mutation prevents flavonoid synthesis and alters auxin transport and the response of Arabidopsis roots to gravity and light. Plant Cell 2004, 16, 1191-1205. [CrossRef] [PubMed]

108. Peer, W.A.; Bandyopadhyay, A.; Blakeslee, J.J.; Makam, S.N.; Chen, R.J.; Masson, P.H.; Murphy, A.S. Variation in Expression and Protein Localization of the PIN Family of Auxin Efflux Facilitator Proteins in Flavonoid Mutants with Altered Auxin Transport in Arabidopsis thaliana. Plant Cell 2004, 16, 1898-1911. [CrossRef] [PubMed]

109. Kuhn, B.M.; Nodzyński, T.; Errafi, S.; Bucher, R.; Gupta, S.; Aryal, B.; Dobrev, P.; Bigler, L.; Geisler, M.; Zažímalová, E.; et al. Flavonol-induced changes in PIN2 polarity and auxin transport in the Arabidopsis thaliana rol1-2 mutant require phosphatase activity. Sci. Rep. 2017. [CrossRef] [PubMed]

110. Buer, C.S.; Kordbacheh, F.; Truong, T.T.; Hocart, C.H.; Djordjevic, M.A. Alteration of flavonoid accumulation patterns in transparent testa mutants disturbs auxin transport, gravity responses, and imparts long-term effects on root and shoot architecture. Planta 2013, 238, 171-189. [CrossRef] [PubMed]

111. Rushton, P.J.; Somssich, I.E.; Ringler, P.; Shen, Q.J. WRKY transcription factors. Trends Plant Sci. 2010, 15, 247-258. [CrossRef] [PubMed]

112. Grunewald, W.; De Smet, I.; Lewis, D.R.; Löfke, C.; Jansen, L.; Goeminne, G.; Vanden Bossche, R.; Karimi, M.; De Rybel, B.; Vanholme, B.; et al. Transcription factor WRKY23 assists auxin distribution patterns during Arabidopsis root development through local control on flavonol biosynthesis. Proc. Natl. Acad. Sci. USA 2012, 109, 1554-1559. [CrossRef] [PubMed]

113. Smith, A.P.; Nourizadeh, S.D.; Peer, W.A.; Xu, J.; Bandyopadhyay, A.; Murphy, A.S.; Goldsbrough, P.B. Arabidopsis AtGSTF2 is regulated by ethylene and auxin, and encodes a glutathione $S$-transferase that interacts with flavonoids. Plant J. 2003, 36, 433-442. [CrossRef] [PubMed]

114. Kokubo, T.; Ambe-Ono, Y.; Nakamura, M.; Ishida, H.; Yamakawa, T.; Kodama, T. Promotive effect of auxins on UDP-glucose: Flavonol glucosyltransferase activity in Vitis sp. cell cultures. J. Biosci. Bioeng. 2001, 91, 564-569. [CrossRef]

115. Silva-Navas, J.; Moreno-Risueno, M.A.; Manzano, C.; Téllez-Robledo, B.; Navarro-Neila, S.; Carrasco, V.; Pollmann, S.; Gallego, F.J.; del Pozo, J.C. Flavonols Mediate Root Phototropism and Growth through Regulation of Proliferation-to-Differentiation Transition. Plant Cell 2016, 28, 1372-1387. [CrossRef] [PubMed]

116. Pasternak, T.; Rudas, V.; Potters, G.; Jansen, M.A.K. Morphogenic effects of abiotic stress: Reorientation of growth in Arabidopsis thaliana seedlings. Environ. Exp. Bot. 2005, 53, 299-314. [CrossRef]

117. Jiang, Y.; Deyholos, M.K. Comprehensive transcriptional profiling of NaCl-stressed Arabidopsis roots reveals novel classes of responsive genes. BMC Plant Biol. 2006, 6, 25. [CrossRef] [PubMed]

118. Liu, W.; Li, R.-J.; Han, T.-T.; Cai, W.; Fu, Z.-W.; Lu, Y.-T. Salt Stress Reduces Root Meristem Size by Nitric Oxide-Mediated Modulation of Auxin Accumulation and Signaling in Arabidopsis. Plant Physiol. 2015, 168, 343-356. [CrossRef] [PubMed]

119. Sun, F.; Zhang, W.; Hu, H.; Li, B.; Wang, Y.; Zhao, Y.; Li, K.; Liu, M.; Li, X. Salt Modulates Gravity Signaling Pathway to Regulate Growth Direction of Primary Roots in Arabidopsis. Plant Physiol. 2008, 146, 178-188. [CrossRef] [PubMed]

120. Yue, R.; Tie, S.; Sun, T.; Zhang, L.; Yang, Y.; Qi, J.; Yan, S.; Han, X.; Wang, H.; Shen, C. Genome-Wide Identification and Expression Profiling Analysis of ZmPIN, ZmPILS, ZmLAX and ZmABCB Auxin Transporter Gene Families in Maize (Zea mays L.) under Various Abiotic Stresses. PLoS ONE 2015, 10, e0118751. [CrossRef] [PubMed] 
121. Geldner, N.; Anders, N.; Wolters, H.; Keicher, J.; Kornberger, W.; Muller, P.; Delbarre, A.; Ueda, T.; Nakano, A.; Jürgens, G. The Arabidopsis GNOM ARF-GEF mediates endosomal recycling, auxin transport, and auxin-dependent plant growth. Cell 2003, 112, 219-230. [CrossRef]

122. Kleine-Vehn, J.; Łangowski, Ł.; Wiśniewska, J.; Dhonukshe, P.; Brewer, P.B.; Friml, J. Cellular and Molecular Requirements for Polar PIN Targeting and Transcytosis in Plants. Mol. Plant 2008, 1, 1056-1066. [CrossRef] [PubMed]

123. Benková, E.; Michniewicz, M.; Sauer, M.; Teichmann, T.; Seifertová, D.; Jürgens, G.; Friml, J. Local, efflux-dependent auxin gradients as a common module for plant organ formation. Cell 2003, 115, 591-602. [CrossRef]

124. Friml, J.; Wiśniewska, J.; Benková, E.; Mendgen, K.; Palme, K. Lateral relocation of auxin efflux regulator PIN3 mediates tropism in Arabidopsis. Nature 2002, 415, 806-809. [CrossRef] [PubMed]

125. Friml, J.; Vieten, A.; Sauer, M.; Weijers, D.; Schwarz, H.; Hamann, T.; Offringa, R.; Jürgens, G. Efflux-dependent auxin gradients establish the apical-basal axis of Arabidopsis. Nature 2003, 426, 147-153. [CrossRef] [PubMed]

126. Reinhardt, D.; Pesce, E.-R.; Stieger, P.; Mandel, T.; Baltensperger, K.; Bennett, M.; Traas, J.; Friml, J.; Kuhlemeier, C. Regulation of phyllotaxis by polar auxin transport. Nature 2003, 426, 255-260. [CrossRef] [PubMed]

127. Heisler, M.G.; Ohno, C.; Das, P.; Sieber, P.; Reddy, G.V.; Long, J.A.; Meyerowitz, E.M. Patterns of Auxin Transport and Gene Expression during Primordium Development Revealed by Live Imaging of the Arabidopsis Inflorescence Meristem. Curr. Biol. 2005, 15, 1899-1911. [CrossRef] [PubMed]

128. Shibasaki, K.; Uemura, M.; Tsurumi, S.; Rahman, A. Auxin Response in Arabidopsis under Cold Stress: Underlying Molecular Mechanisms. Plant Cell 2009, 21, 3823-3838. [CrossRef] [PubMed]

129. Zwiewka, M.; Nodzyński, T.; Robert, S.; Vanneste, S.; Friml, J. Osmotic Stress Modulates the Balance between Exocytosis and Clathrin-Mediated Endocytosis in Arabidopsis thaliana. Mol. Plant 2015, 8, 1175-1187. [CrossRef] [PubMed]

130. Galvan-Ampudia, C.S.; Julkowska, M.M.; Darwish, E.; Gandullo, J.; Korver, R.A.; Brunoud, G.; Haring, M.A.; Munnik, T.; Vernoux, T.; Testerink, C. Halotropism Is a Response of Plant Roots to Avoid a Saline Environment. Curr. Biol. 2013, 23, 2044-2050. [CrossRef] [PubMed]

131. Bishopp, A.; Help, H.; El-Showk, S.; Weijers, D.; Scheres, B.; Friml, J.; Benková, E.; Mähönen, A.P.; Helariutta, Y. A Mutually Inhibitory Interaction between Auxin and Cytokinin Specifies Vascular Pattern in Roots. Curr. Biol. 2011, 21, 917-926. [CrossRef] [PubMed]

132. Gillissen, B.; Bürkle, L.; André, B.; Kühn, C.; Rentsch, D.; Brandl, B.; Frommer, W.B. A New Family of High-Affinity Transporters for Adenine, Cytosine, and Purine Derivatives in Arabidopsis. Plant Cell 2000, 12, 291-300. [CrossRef] [PubMed]

133. Kudo, T.; Kiba, T.; Sakakibara, H. Metabolism and Long-distance Translocation of Cytokinins. J. Integr. Plant Biol. 2010, 52, 53-60. [CrossRef] [PubMed]

134. Bürkle, L.; Cedzich, A.; Döpke, C.; Stransky, H.; Okumoto, S.; Gillissen, B.; Kühn, C.; Frommer, W.B. Transport of cytokinins mediated by purine transporters of the PUP family expressed in phloem, hydathodes, and pollen of Arabidopsis. Plant J. 2003, 34, 13-26. [CrossRef] [PubMed]

135. Hirose, N.; Takei, K.; Kuroha, T.; Kamada-Nobusada, T.; Hayashi, H.; Sakakibara, H. Regulation of cytokinin biosynthesis, compartmentalization and translocation. J. Exp. Bot. 2007, 59, 75-83. [CrossRef] [PubMed]

136. Bishopp, A.; Lehesranta, S.; Vatén, A.; Help, H.; El-Showk, S.; Scheres, B.; Helariutta, K.; Mähönen, A.P.; Sakakibara, H.; Helariutta, Y. Phloem-Transported Cytokinin Regulates Polar Auxin Transport and Maintains Vascular Pattern in the Root Meristem. Curr. Biol. 2011, 21, 927-932. [CrossRef] [PubMed]

137. Ko, D.; Kang, J.; Kiba, T.; Park, J.; Kojima, M.; Do, J.; Kim, K.Y.; Kwon, M.; Endler, A.; Song, W.-Y.; et al. Arabidopsis ABCG14 is essential for the root-to-shoot translocation of cytokinin. Proc. Natl. Acad. Sci. USA 2014, 111, 7150-7155. [CrossRef] [PubMed]

138. Zhang, K.; Novak, O.; Wei, Z.; Gou, M.; Zhang, X.; Yu, Y.; Yang, H.; Cai, Y.; Strnad, M.; Liu, C.-J. Arabidopsis ABCG14 protein controls the acropetal translocation of root-synthesized cytokinins. Nat. Commun. 2014, 5, 3274. [CrossRef] [PubMed]

139. Ulmasov, T.; Murfett, J.; Hagen, G.; Guilfoyle, T.J. Aux/IAA proteins repress expression of reporter genes containing natural and highly active synthetic auxin response elements. Plant Cell Online 1997, 9, 1963-1971. [CrossRef] [PubMed] 
140. Shu, W.; Liu, Y.; Guo, Y.; Zhou, H.; Zhang, J.; Zhao, S.; Lu, M. A Populus TIR1 gene family survey reveals differential expression patterns and responses to 1-naphthaleneacetic acid and stress treatments. Front. Plant Sci. 2015, 6, 719. [PubMed]

141. Blomster, T.; Salojarvi, J.; Sipari, N.; Brosche, M.; Ahlfors, R.; Keinanen, M.; Overmyer, K.; Kangasjarvi, J. Apoplastic Reactive Oxygen Species Transiently Decrease Auxin Signaling and Cause Stress-Induced Morphogenic Response in Arabidopsis. Plant Physiol. 2011, 157, 1866-1883. [CrossRef] [PubMed]

142. Farcot, E.; Lavedrine, C.; Vernoux, T. A modular analysis of the auxin signalling network. PLoS ONE 2015, 10, e0122231. [CrossRef] [PubMed]

143. Iglesias, M.J.; Terrile, M.C.; Bartoli, C.G.; D’Ippólito, S.; Casalongué, C.A. Auxin signaling participates in the adaptative response against oxidative stress and salinity by interacting with redox metabolism in Arabidopsis. Plant Mol. Biol. 2010, 74, 215-222. [CrossRef] [PubMed]

144. Ha, C.V.; Le, D.T.; Nishiyama, R.; Watanabe, Y.; Sulieman, S.; Tran, U.T.; Mochida, K.; Dong, N.V.; Yamaguchi-Shinozaki, K.; Shinozaki, K.; et al. The auxin response factor transcription factor family in soybean: Genome-wide identification and expression analyses during development and water stress. DNA Res. Int. J. Rapid Publ. Rep. Genes Genomes 2013, 20, 511-524.

145. Jain, M.; Khurana, J.P. Transcript profiling reveals diverse roles of auxin-responsive genes during reproductive development and abiotic stress in rice. FEBS J. 2009, 276, 3148-3162. [CrossRef] [PubMed]

146. Wang, S.; Bai, Y.; Shen, C.; Wu, Y.; Zhang, S.; Jiang, D.; Guilfoyle, T.J.; Chen, M.; Qi, Y. Auxin-related gene families in abiotic stress response in Sorghum bicolor. Funct. Integr. Genom. 2010, 10, 533-546. [CrossRef] [PubMed]

147. Jung, H.; Lee, D.-K.; Choi, Y.D.; Kim, J.-K. OsIAA6, a member of the rice Aux/IAA gene family, is involved in drought tolerance and tiller outgrowth. Plant Sci. 2015, 236, 304-312. [CrossRef] [PubMed]

148. Matsui, A.; Ishida, J.; Morosawa, T.; Mochizuki, Y.; Kaminuma, E.; Endo, T.A.; Okamoto, M.; Nambara, E.; Nakajima, M.; Kawashima, M.; et al. Arabidopsis Transcriptome Analysis under Drought, Cold, High-Salinity and ABA Treatment Conditions using a Tiling Array. Plant Cell Physiol. 2008, 49, 1135-1149. [CrossRef] [PubMed]

149. Sun, X.; Xu, L.; Wang, Y.; Yu, R.; Zhu, X.; Luo, X.; Gong, Y.; Wang, R.; Limera, C.; Zhang, K.; et al. Identification of novel and salt-responsive miRNAs to explore miRNA-mediated regulatory network of salt stress response in radish (Raphanus sativus L.). BMC Genom. 2015, 16, 197. [CrossRef] [PubMed]

150. Liu, H.-H.; Tian, X.; Li, Y.-J.; Wu, C.-A.; Zheng, C.-C. Microarray-based analysis of stress-regulated microRNAs in Arabidopsis thaliana. RNA 2008, 14, 836-843. [CrossRef] [PubMed]

151. Zürcher, E.; Müller, B. Cytokinin Synthesis, Signaling, and Function-Advances and New Insights. Int. Rev. Cell Mol. Biol. 2016, 324, 1-38. [PubMed]

152. Argyros, R.D.; Mathews, D.E.; Chiang, Y.-H.; Palmer, C.M.; Thibault, D.M.; Etheridge, N.; Argyros, D.A.; Mason, M.G.; Kieber, J.J.; Schaller, G.E. Type B Response Regulators of Arabidopsis Play Key Roles in Cytokinin Signaling and Plant Development. Plant Cell Online 2008, 20, 2102-2116. [CrossRef] [PubMed]

153. Sakai, H.; Aoyama, T.; Bono, H.; Oka, A. Two-Component Response Regulators from Arabidopsis thaliana Contain a Putative DNA-Binding Motif. Plant Cell Physiol. 1998, 39, 1232-1239. [CrossRef] [PubMed]

154. Sakai, H.; Aoyama, T.; Oka, A. Arabidopsis ARR1 and ARR2 response regulators operate as transcriptional activators. Plant J. Cell Mol. Biol. 2000, 24, 703-711. [CrossRef]

155. Sakai, H.; Honma, T.; Aoyama, T.; Sato, S.; Kato, T.; Tabata, S.; Oka, A. ARR1, a transcription factor for genes immediately responsive to cytokinins. Science 2001, 294, 1519-1521. [CrossRef] [PubMed]

156. Brandstatter, I.; Kieber, J.J. Two genes with similarity to bacterial response regulators are rapidly and specifically induced by cytokinin in Arabidopsis. Plant Cell 1998, 10, 1009-1019. [CrossRef] [PubMed]

157. D'Agostino, I.B.; Deruère, J.; Kieber, J.J. Characterization of the response of the Arabidopsis response regulator gene family to cytokinin. Plant Physiol. 2000, 124, 1706-1717. [CrossRef] [PubMed]

158. Hwang, I.; Sheen, J. Two-component circuitry in Arabidopsis cytokinin signal transduction. Nature 2001, 413, 383-389. [CrossRef] [PubMed]

159. Tran, L.-S.P.; Urao, T.; Qin, F.; Maruyama, K.; Kakimoto, T.; Shinozaki, K.; Yamaguchi-Shinozaki, K. Functional analysis of AHK1/ATHK1 and cytokinin receptor histidine kinases in response to abscisic acid, drought, and salt stress in Arabidopsis. Proc. Natl. Acad. Sci. USA 2007, 104, 20623-20628. [CrossRef] [PubMed]

160. Kumar, M.N.; Verslues, P.E. Stress physiology functions of the Arabidopsis histidine kinase cytokinin receptors. Physiol. Plant. 2015, 154, 369-380. [CrossRef] [PubMed] 
161. Jeon, J.; Kim, N.Y.; Kim, S.; Kang, N.Y.; Novak, O.; Ku, S.-J.; Cho, C.; Lee, D.J.; Lee, E.-J.; Strnad, M.; et al. A Subset of Cytokinin Two-component Signaling System Plays a Role in Cold Temperature Stress Response in Arabidopsis. J. Biol. Chem. 2010, 285, 23371-23386. [CrossRef] [PubMed]

162. Jeon, J.; Kim, J. Arabidopsis Response Regulator1 and Arabidopsis Histidine Phosphotransfer Protein2 (AHP2), AHP3, and AHP5 Function in Cold Signaling. Plant Physiol. 2013, 161, 408-424. [CrossRef] [PubMed]

163. Kang, N.Y.; Cho, C.; Kim, J. Inducible Expression of Arabidopsis Response Regulator 22 (ARR22), a Type-C ARR, in Transgenic Arabidopsis Enhances Drought and Freezing Tolerance. PLoS ONE 2013. [CrossRef] [PubMed]

164. Bhargava, A.; Clabaugh, I.; To, J.P.; Maxwell, B.B.; Chiang, Y.-H.; Schaller, G.E.; Loraine, A.; Kieber, J.J. Identification of Cytokinin-Responsive Genes Using Microarray Meta-Analysis and RNA-Seq in Arabidopsis. Plant Physiol. 2013, 162, 272-294. [CrossRef] [PubMed]

165. Brenner, W.G.; Schmulling, T. Transcript profiling of cytokinin action in Arabidopsis roots and shoots discovers largely similar but also organ-specific responses. BMC Plant Biol. 2012, 12, 112. [CrossRef] [PubMed]

166. Kocsy, G.; Tari, I.; Vanková, R.; Zechmann, B.; Gulyás, Z.; Poór, P.; Galiba, G. Redox control of plant growth and development. Plant Sci. 2013, 211,77-91. [CrossRef] [PubMed]

167. Reguera, M.; Peleg, Z.; Abdel-Tawab, Y.M.; Tumimbang, E.B.; Delatorre, C.A.; Blumwald, E. Stress-Induced Cytokinin Synthesis Increases Drought Tolerance through the Coordinated Regulation of Carbon and Nitrogen Assimilation in Rice. Plant Physiol. 2013, 163, 1609-1622. [CrossRef] [PubMed]

168. Kang, N.Y.; Cho, C.; Kim, N.Y.; Kim, J. Cytokinin receptor-dependent and receptor-independent pathways in the dehydration response of Arabidopsis thaliana. J. Plant Physiol. 2012, 169, 1382-1391. [CrossRef] [PubMed]

169. Dello Ioio, R.; Linhares, F.S.; Scacchi, E.; Casamitjana-Martinez, E.; Heidstra, R.; Costantino, P.; Sabatini, S. Cytokinins Determine Arabidopsis Root-Meristem Size by Controlling Cell Differentiation. Curr. Biol. 2007, 17, 678-682. [CrossRef] [PubMed]

170. Nishiyama, R.; Watanabe, Y.; Leyva-Gonzalez, M.A.; Van Ha, C.; Fujita, Y.; Tanaka, M.; Seki, M.; Yamaguchi-Shinozaki, K.; Shinozaki, K.; Herrera-Estrella, L.; et al. Arabidopsis AHP2, AHP3, and AHP5 histidine phosphotransfer proteins function as redundant negative regulators of drought stress response. Proc. Natl. Acad. Sci. USA 2013, 110, 4840-4845. [CrossRef] [PubMed]

171. Sun, L.; Zhang, Q.; Wu, J.; Zhang, L.; Jiao, X.; Zhang, S.; Zhang, Z.; Sun, D.; Lu, T.; Sun, Y. Two Rice Authentic Histidine Phosphotransfer Proteins, OsAHP1 and OsAHP2, Mediate Cytokinin Signaling and Stress Responses in Rice. Plant Physiol. 2014, 165, 335-345. [CrossRef] [PubMed]

172. Mason, M.G.; Jha, D.; Salt, D.E.; Tester, M.; Hill, K.; Kieber, J.J.; Eric Schaller, G. Type-B response regulators ARR1 and ARR12 regulate expression of AtHKT1;1 and accumulation of sodium in Arabidopsis shoots. Plant J. 2010, 64, 753-763. [CrossRef] [PubMed]

173. Rashotte, A.M.; Mason, M.G.; Hutchison, C.E.; Ferreira, F.J.; Schaller, G.E.; Kieber, J.J. A subset of Arabidopsis AP2 transcription factors mediates cytokinin responses in concert with a two-component pathway. Proc. Natl. Acad. Sci. USA 2006, 103, 11081-11085. [CrossRef] [PubMed]

174. Shi, X.; Gupta, S.; Rashotte, A.M. Characterization of two tomato AP2/ERF genes, SICRF1 and SICRF2 in hormone and stress responses. Plant Cell Rep. 2014, 33, 35-45. [CrossRef] [PubMed]

175. Inzé, A.; Vanderauwera, S.; Hoeberichts, F.A.; Vandorpe, M.; van Gaever, T.; Van Breusegem, F. A subcellular localization compendium of hydrogen peroxide-induced proteins. Plant Cell Environ. 2012, 35, 308-320. [CrossRef] [PubMed]

176. Zwack, P.J.; Robinson, B.R.; Risley, M.G.; Rashotte, A.M. Cytokinin Response Factor 6 Negatively Regulates Leaf Senescence and is Induced in Response to Cytokinin and Numerous Abiotic Stresses. Plant Cell Physiol. 2013, 54, 971-981. [CrossRef] [PubMed]

177. Zwack, P.J.; De Clercq, I.; Howton, T.C.; Hallmark, H.T.; Hurny, A.; Keshishian, E.A.; Parish, A.M.; Benkova, E.; Mukhtar, M.S.; Van Breusegem, F.; et al. Cytokinin Response Factor 6 Represses Cytokinin-Associated Genes during Oxidative Stress. Plant Physiol. 2016, 172, 1249-1258. [CrossRef] [PubMed]

178. Gupta, S.; Rashotte, A.M. Expression patterns and regulation of SICRF3 and SICRF5 in response to cytokinin and abiotic stresses in tomato (Solanum lycopersicum). J. Plant Physiol. 2014, 171, 349-358. [CrossRef] [PubMed] 
179. De Clercq, I.; Vermeirssen, V.; van Aken, O.; Vandepoele, K.; Murcha, M.W.; Law, S.R.; Inzé, A.; Ng, S.; Ivanova, A.; Rombaut, D.; et al. The membrane-bound NAC transcription factor ANAC013 functions in mitochondrial retrograde regulation of the oxidative stress response in Arabidopsis. Plant Cell 2013, 25, 3472-3490. [CrossRef] [PubMed]

180. Ng, S.; Ivanova, A.; Duncan, O.; Law, S.R.; Van Aken, O.; de Clercq, I.; Wang, Y.; Carrie, C.; Xu, L.; Kmiec, B.; et al. A membrane-bound NAC transcription factor, ANAC017, mediates mitochondrial retrograde signaling in Arabidopsis. Plant Cell 2013, 25, 3450-3471. [CrossRef] [PubMed]

181. Zwack, P.J.; Compton, M.A.; Adams, C.I.; Rashotte, A.M. Cytokinin response factor 4 (CRF4) is induced by cold and involved in freezing tolerance. Plant Cell Rep. 2015, 1-12. [CrossRef] [PubMed]

182. Feng, J.; Wang, C.; Chen, Q.; Chen, H.; Ren, B.; Li, X.; Zuo, J. S-nitrosylation of phosphotransfer proteins represses cytokinin signaling. Nat. Commun. 2013, 4, 1529. [CrossRef] [PubMed]

183. Terrile, M.C.; París, R.; Calderón-Villalobos, L.I.A.; Iglesias, M.J.; Lamattina, L.; Estelle, M.; Casalongué, C.A. Nitric Oxide Influences Auxin Signaling through S-nitrosylation of the Arabidopsis Transport Inhibitor Response1 Auxin Receptor. Plant J. 2012, 70, 492-500. [CrossRef] [PubMed]

184. Jones, B.; Ljung, K. Auxin and cytokinin regulate each other's levels via a metabolic feedback loop. Plant Signal. Behav. 2011, 6, 901-904. [CrossRef] [PubMed]

185. Birnbaum, K.D. How many ways are there to make a root? Curr. Opin. Plant Biol. 2016, 34, 61-67. [CrossRef] [PubMed]

186. De Rybel, B.; Mähönen, A.P.; Helariutta, Y.; Weijers, D. Plant vascular development: From early specification to differentiation. Nat. Rev. Mol. Cell Biol. 2016, 17, 30-40. [CrossRef] [PubMed]

187. Naseem, M.; Kaltdorf, M.; Dandekar, T. The nexus between growth and defence signalling: Auxin and cytokinin modulate plant immune response pathways. J. Exp. Bot. 2015, 66, 4885-4896. [CrossRef] [PubMed]

188. Miyawaki, K.; Matsumoto-Kitano, M.; Kakimoto, T. Expression of cytokinin biosynthetic isopentenyltransferase genes in Arabidopsis: Tissue specificity and regulation by auxin, cytokinin, and nitrate. Plant J. Cell Mol. Biol. 2004, 37, 128-138. [CrossRef]

189. Dello Ioio, R.; Nakamura, K.; Moubayidin, L.; Perilli, S.; Taniguchi, M.; Morita, M.T.; Aoyama, T.; Costantino, P.; Sabatini, S. A genetic framework for the control of cell division and differentiation in the root meristem. Science 2008, 322, 1380-1384. [CrossRef] [PubMed]

190. Tanaka, M.; Takei, K.; Kojima, M.; Sakakibara, H.; Mori, H. Auxin controls local cytokinin biosynthesis in the nodal stem in apical dominance. Plant J. 2006, 45, 1028-1036. [CrossRef] [PubMed]

191. Nordström, A.; Tarkowski, P.; Tarkowska, D.; Norbaek, R.; Astot, C.; Dolezal, K.; Sandberg, G. Auxin regulation of cytokinin biosynthesis in Arabidopsis thaliana: A factor of potential importance for auxin-cytokinin-regulated development. Proc. Natl. Acad. Sci. USA 2004, 101, 8039-8044. [CrossRef] [PubMed]

192. Werner, T.; Köllmer, I.; Bartrina, I.; Holst, K.; Schmülling, T. New Insights into the Biology of Cytokinin Degradation. Plant Biol. 2006, 8, 371-381. [CrossRef] [PubMed]

193. Carabelli, M.; Possenti, M.; Sessa, G.; Ciolfi, A.; Sassi, M.; Morelli, G.; Ruberti, I. Canopy shade causes a rapid and transient arrest in leaf development through auxin-induced cytokinin oxidase activity. Genes Dev. 2007, 21, 1863-1868. [CrossRef] [PubMed]

194. Jones, B.; Gunnerås, S.A.; Petersson, S.V.; Tarkowski, P.; Graham, N.; May, S.; Dolezal, K.; Sandberg, G.; Ljung, K. Cytokinin regulation of auxin synthesis in Arabidopsis involves a homeostatic feedback loop regulated via auxin and cytokinin signal transduction. Plant Cell 2010, 22, 2956-2969. [CrossRef] [PubMed]

195. Polanská, L.; Vicánková, A.; Nováková, M.; Malbeck, J.; Dobrev, P.I.; Brzobohaty, B.; Vanková, R.; Machácková, I. Altered cytokinin metabolism affects cytokinin, auxin, and abscisic acid contents in leaves and chloroplasts, and chloroplast ultrastructure in transgenic tobacco. J. Exp. Bot. 2007, 58, 637-649. [CrossRef] [PubMed]

196. Müller, B.; Sheen, J. Cytokinin and auxin interaction in root stem-cell specification during early embryogenesis. Nature 2008, 453, 1094-1097. [CrossRef] [PubMed]

197. Zhao, Z.; Andersen, S.U.; Ljung, K.; Dolezal, K.; Miotk, A.; Schultheiss, S.J.; Lohmann, J.U. Hormonal control of the shoot stem-cell niche. Nature 2010, 465, 1089-1092. [CrossRef] [PubMed]

198. Moubayidin, L.; Perilli, S.; Dello Ioio, R.; Di Mambro, R.; Costantino, P.; Sabatini, S. The rate of cell differentiation controls the Arabidopsis root meristem growth phase. Curr. Biol. 2010, 20, 1138-1143. [CrossRef] [PubMed] 
199. Pernisová, M.; Klíma, P.; Horák, J.; Válková, M.; Malbeck, J.; Souček, P.; Reichman, P.; Hoyerová, K.; Dubová, J.; Friml, J.; et al. Cytokinins modulate auxin-induced organogenesis in plants via regulation of the auxin efflux. Proc. Natl. Acad. Sci. USA 2009, 106, 3609-3614. [CrossRef] [PubMed]

200. Marhavý, P.; Bielach, A.; Abas, L.; Abuzeineh, A.; Duclercq, J.; Tanaka, H.; Pařezová, M.; Petrášek, J.; Friml, J.; Kleine-Vehn, J.; et al. Cytokinin Modulates Endocytic Trafficking of PIN1 Auxin Efflux Carrier to Control Plant Organogenesis. Dev. Cell 2011, 21, 796-804. [CrossRef] [PubMed]

201. Rǔžička, K.; Šimášková, M.; Duclercq, J.; Petrášek, J.; Zažímalová, E.; Simon, S.; Friml, J.; Van Montagu, M.C.; Benková, E. Cytokinin regulates root meristem activity via modulation of the polar auxin transport. Proc. Natl. Acad. Sci. USA 2009, 106, 4284-4289. [CrossRef] [PubMed]

202. Moreira, S.; Bishopp, A.; Carvalho, H.; Campilho, A. AHP6 Inhibits Cytokinin Signaling to Regulate the Orientation of Pericycle Cell Division during Lateral Root Initiation. PLoS ONE 2013. [CrossRef] [PubMed]

203. Kuppusamy, K.T.; Walcher, C.L.; Nemhauser, J.L. Cross-regulatory mechanisms in hormone signaling. Plant Mol. Biol. 2009, 69, 375-381. [CrossRef] [PubMed]

204. Ramireddy, E.; Chang, L.; Schmülling, T. Cytokinin as a mediator for regulating root system architecture in response to environmental cues. Plant Signal. Behav. 2014. [CrossRef]

205. Hruz, T.; Laule, O.; Szabo, G.; Wessendorp, F.; Bleuler, S.; Oertle, L.; Widmayer, P.; Gruissem, W.; Zimmermann, P. Genevestigator V3: A Reference Expression Database for the Meta-Analysis of Transcriptomes. Adv. Bioinform. 2008, 2008, e420747. [CrossRef] [PubMed]

206. Bennett, T.; Hines, G.; van Rongen, M.; Waldie, T.; Sawchuk, M.G.; Scarpella, E.; Ljung, K.; Leyser, O. Connective Auxin Transport in the Shoot Facilitates Communication between Shoot Apices. PLoS Biol. 2016, 14, e1002446. [CrossRef] [PubMed]

207. Bainbridge, K.; Guyomarc'h, S.; Bayer, E.; Swarup, R.; Bennett, M.; Mandel, T.; Kuhlemeier, C. Auxin influx carriers stabilize phyllotactic patterning. Genes Dev. 2008, 22, 810-823. [CrossRef] [PubMed]

208. Revalska, M.; Vassileva, V.; Zechirov, G.; Iantcheva, A. Is the auxin influx carrier LAX3 essential for plant growth and development in the model plants Medicago truncatula, Lotus japonicus and Arabidopsis thaliana? Biotechnol. Biotechnol. Equip. 2015, 29, 786-797. [CrossRef]

209. Wolters, H.; Anders, N.; Geldner, N.; Gavidia, R.; Jürgens, G. Coordination of apical and basal embryo development revealed by tissue-specific GNOM functions. Development 2011, 138, 117-126. [CrossRef] [PubMed]

210. Ren, H.; Gray, W.M. SAUR Proteins as Effectors of Hormonal and Environmental Signals in Plant Growth. Mol. Plant 2015, 8, 1153. [CrossRef] [PubMed]

211. Chae, K.; Isaacs, C.G.; Reeves, P.H.; Maloney, G.S.; Muday, G.K.; Nagpal, P.; Reed, J.W. Arabidopsis SMALL AUXIN UP RNA63 promotes hypocotyl and stamen filament elongation. Plant J. 2012, 71, 684-697. [CrossRef] [PubMed]

212. Spartz, A.K.; Ren, H.; Park, M.Y.; Grandt, K.N.; Lee, S.H.; Murphy, A.S.; Sussman, M.R.; Overvoorde, P.J.; Gray, W.M. SAUR Inhibition of PP2C-D Phosphatases Activates Plasma Membrane H+-ATPases to Promote Cell Expansion in Arabidopsis. Plant Cell 2014, 26, 2129-2142. [CrossRef] [PubMed]

213. Chen, D.; Richardson, T.; Chai, S.; McIntyre, C.L.; Rae, A.L.; Xue, G.-P. Drought-Up-Regulated TaNAC69-1 is a Transcriptional Repressor of TaSHY2 and TaIAA7, and Enhances Root Length and Biomass in Wheat. Plant Cell Physiol. 2016, 57, 2076-2090. [CrossRef] [PubMed]

214. Fan, M.; Bai, M.-Y.; Kim, J.-G.; Wang, T.; Oh, E.; Chen, L.; Park, C.H.; Son, S.-H.; Kim, S.-K.; Mudgett, M.B.; et al. The bHLH transcription factor HBI1 mediates the trade-off between growth and pathogen-associated molecular pattern-triggered immunity in Arabidopsis. Plant Cell 2014, 26, 828-841. [CrossRef] [PubMed]

215. Benekos, K.; Kissoudis, C.; Nianiou-Obeidat, I.; Labrou, N.; Madesis, P.; Kalamaki, M.; Makris, A.; Tsaftaris, A. Overexpression of a specific soybean GmGSTU4 isoenzyme improves diphenyl ether and chloroacetanilide herbicide tolerance of transgenic tobacco plants. J. Biotechnol. 2010, 150, 195-201. [CrossRef] [PubMed]

216. Jha, Y.; Subramanian, R.B.; Patel, S. Combination of endophytic and rhizospheric plant growth promoting rhizobacteria in Oryza sativa shows higher accumulation of osmoprotectant against saline stress. Acta Physiol. Plant. 2011, 33, 797-802. [CrossRef]

217. Roxas, V.P.; Smith, R.K.; Allen, E.R.; Allen, R.D. Overexpression of glutathione S-transferase/glutathioneperoxidase enhances the growth of transgenic tobacco seedlings during stress. Nat. Biotechnol. 1997, 15, 988-991. [CrossRef] [PubMed] 
218. Sharma, R.; Sahoo, A.; Devendran, R.; Jain, M. Over-Expression of a Rice Tau Class Glutathione S-Transferase Gene Improves Tolerance to Salinity and Oxidative Stresses in Arabidopsis. PLoS ONE 2014. [CrossRef] [PubMed]

219. Tiwari, V.; Patel, M.K.; Chaturvedi, A.K.; Mishra, A.; Jha, B. Functional Characterization of the Tau Class Glutathione-S-Transferases Gene (SbGSTU) Promoter of Salicornia brachiata under Salinity and Osmotic Stress. PLoS ONE 2016. [CrossRef] [PubMed]

220. Diaz-Vivancos, P.; de Simone, A.; Kiddle, G.; Foyer, C.H. Glutathione-Linking cell proliferation to oxidative stress. Free Radic. Biol. Med. 2015, 89, 1154-1164. [CrossRef] [PubMed]

221. Foyer, C.H.; Noctor, G. Ascorbate and Glutathione: The Heart of the Redox Hub. Plant Physiol. 2011, 155, 2-18. [CrossRef] [PubMed]

222. Noctor, G.; Mhamdi, A.; Chaouch, S.; Han, Y.; Neukermans, J.; Marquez-Garcia, B.; Queval, G.; Foyer, C.H. Glutathione in plants: An integrated overview. Plant Cell Environ. 2012, 35, 454-484. [CrossRef] [PubMed]

223. Passaia, G.; Queval, G.; Bai, J.; Margis-Pinheiro, M.; Foyer, C.H. The effects of redox controls mediated by glutathione peroxidases on root architecture in Arabidopsis thaliana. J. Exp. Bot. 2014, 65, 1403-1413. [CrossRef] [PubMed]

224. Remy, E.; Cabrito, T.R.; Baster, P.; Batista, R.A.; Teixeira, M.C.; Friml, J.; Sa-Correia, I.; Duque, P. A Major Facilitator Superfamily Transporter Plays a Dual Role in Polar Auxin Transport and Drought Stress Tolerance in Arabidopsis. Plant Cell 2013, 25, 901-926. [CrossRef] [PubMed]

225. Kamimoto, Y.; Terasaka, K.; Hamamoto, M.; Takanashi, K.; Fukuda, S.; Shitan, N.; Sugiyama, A.; Suzuki, H.; Shibata, D.; Wang, B.; et al. Arabidopsis ABCB21 is a Facultative Auxin Importer/Exporter Regulated by Cytoplasmic Auxin Concentration. Plant Cell Physiol. 2012, 53, 2090-2100. [CrossRef] [PubMed]

226. Terasaka, K.; Blakeslee, J.J.; Titapiwatanakun, B.; Peer, W.A.; Bandyopadhyay, A.; Makam, S.N.; Lee, O.R.; Richards, E.L.; Murphy, A.S.; Sato, F.; et al. PGP4, an ATP Binding Cassette P-Glycoprotein, Catalyzes Auxin Transport in Arabidopsis thaliana Roots. Plant Cell 2005, 17, 2922-2939. [CrossRef] [PubMed]

227. Barbez, E.; Kubeš, M.; Rolčík, J.; Béziat, C.; Pěnčík, A.; Wang, B.; Rosquete, M.R.; Zhu, J.; Dobrev, P.I.; Lee, Y.; et al. A novel putative auxin carrier family regulates intracellular auxin homeostasis in plants. Nature 2012, 485, 119-122. [CrossRef] [PubMed]

228. Sugawara, S.; Hishiyama, S.; Jikumaru, Y.; Hanada, A.; Nishimura, T.; Koshiba, T.; Zhao, Y.; Kamiya, Y.; Kasahara, H. Biochemical analyses of indole-3-acetaldoxime-dependent auxin biosynthesis in Arabidopsis. Proc. Natl. Acad. Sci. USA 2009, 106, 5430-5435. [CrossRef] [PubMed]

229. Zhao, Y. Auxin Biosynthesis. Arabidopsis Book Am. Soc. Plant Biol. 2014. [CrossRef] [PubMed]

230. Mellor, N.; Band, L.R.; Pěnčík, A.; Novák, O.; Rashed, A.; Holman, T.; Wilson, M.H.; Voß, U.; Bishopp, A.; King, J.R.; et al. Dynamic regulation of auxin oxidase and conjugating enzymes AtDAO1 and GH3 modulates auxin homeostasis. Proc. Natl. Acad. Sci. USA 2016, 113, 11022-11027. [CrossRef] [PubMed]

231. Bou-Torrent, J.; Salla-Martret, M.; Brandt, R.; Musielak, T.; Palauqui, J.-C.; Martínez-García, J.F.; Wenkel, S. ATHB4 and HAT3, two class II HD-ZIP transcription factors, control leaf development in Arabidopsis. Plant Signal. Behav. 2012, 7, 1382-1387. [CrossRef] [PubMed]

232. Hu, Y.; Xie, Q.; Chua, N.-H. The Arabidopsis Auxin-Inducible Gene ARGOS Controls Lateral Organ Size. Plant Cell 2003, 15, 1951. [CrossRef] [PubMed]

233. Shi, J.; Habben, J.E.; Archibald, R.L.; Drummond, B.J.; Chamberlin, M.A.; Williams, R.W.; Lafitte, H.R.; Weers, B.P. Overexpression of ARGOS Genes Modifies Plant Sensitivity to Ethylene, Leading to Improved Drought Tolerance in Both Arabidopsis and Maize. Plant Physiol. 2015, 169, 266-282. [CrossRef] [PubMed]

234. Rawat, R.; Schwartz, J.; Jones, M.A.; Sairanen, I.; Cheng, Y.; Andersson, C.R.; Zhao, Y.; Ljung, K.; Harmer, S.L. REVEILLE1, a Myb-like transcription factor, integrates the circadian clock and auxin pathways. Proc. Natl. Acad. Sci. USA 2009, 106, 16883-16888. [CrossRef] [PubMed] 
235. Kim, H.J.; Chiang, Y.-H.; Kieber, J.J.; Schaller, G.E. SCFKMD controls cytokinin signaling by regulating the degradation of type-B response regulators. Proc. Natl. Acad. Sci. USA 2013, 110, 10028. [CrossRef] [PubMed]

236. Zhang, X.; Gou, M.; Guo, C.; Yang, H.; Liu, C.-J. Down-Regulation of Kelch Domain-Containing F-Box Protein in Arabidopsis Enhances the Production of (Poly) phenols and Tolerance to Ultraviolet Radiation. Plant Physiol. 2015, 167, 337. [CrossRef] [PubMed] 